\title{
Variability in the zooplankton assemblages in relation to environmental variables in the tidal creeks of Sundarban estuarine system, India
}

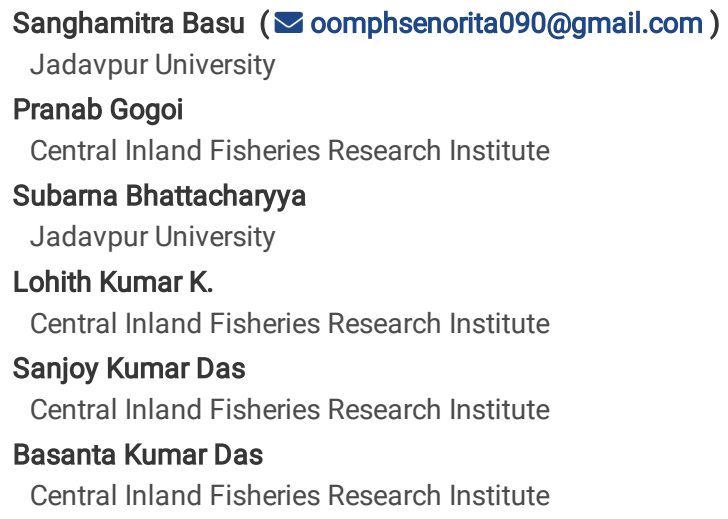

\section{Research Article}

Keywords: Zooplankton, diversity, assemblage, environmental parameters, Sundarbans

Posted Date: June 7th, 2021

DOI: https://doi.org/10.21203/rs.3.rs-183370/v1

License: (c) (1) This work is licensed under a Creative Commons Attribution 4.0 International License. Read Full License

Version of Record: A version of this preprint was published at Environmental Science and Pollution Research on February 14th, 2022. See the published version at https://doi.org/10.1007/s11356-022-19136-8. 


\section{Abstract}

The present study illustrates a holistic account of zooplankton community dynamics in relation to physico - chemical variables in the tidal creeks of Indian Sundarbans estuarine system. Out of 11 water parameters, seven parameters (Temp., salinity, DO, turbidity, $\mathrm{PO}_{4}-\mathrm{P}, \mathrm{NO}_{3}-\mathrm{N}$ and $\mathrm{NO}_{2}-\mathrm{N}$ ) differed significantly $(p \leq 0.05)$ among seasons. A total of 63 zooplankton taxa were recorded with the predominance of Copepoda, varying in ranges from 59.55 to $73.13 \%$ of the total zooplankton population. PERMANOVA design depicted the significant variations of zooplankton population both spatially $(F=2.313$; $p=$ $0.001)$ and temporally $(F=6.107 ; p=0.001)$. Out of 41 species of Copepoda recorded, 14 species (Paracalanous parvus, Parvocalanous dubia, Bestiolina similis, Acrocalanous gibber, A. gracilis, Acartia erythraea, A. spinicauda, Pseudodiaptomus serricaudatus, $P$. annandalei, $P$. aurivilli, Oithona brevicornis, $O$. similis, Longipedia weberi and Microsetella norvegica) indicated as 'characterizing species' in the creek environment, and highlighted the euryhaline nature as well as broad range of thermal tolerance of these species. $\beta$ - diversity index (Index of Multivariate dispersion) reflected higher values $(\beta=>1)$ in the creeks (S4, S2 and S6), those are experienced with high anthropogenic pressure. On the whole, the calculated mean value of $\alpha-$ diversity $\left(d \mathbb{V}=4.07 ; H^{\prime}=2.31\right)$ indicated 'good'zooplankton diversity. Water parameters viz., Temp., salinity, $\mathrm{DO}$, turbidity, $\mathrm{PO}_{4}-\mathrm{P}$ and $\mathrm{NO}_{3}-\mathrm{N}$ were found to have influence on the distribution, abundance and diversity of zooplankton in the creeks. More specifically, the linear model (DistLM) exhibited two variables viz., temperature and salinity were the primary controlling factors in shaping the zooplankton community compositions in the creek environment.

\section{Introduction}

Tropical and sub-tropical regions of the world are home to diverse assemblage of species (Cornils et al. 2007). Plankton are cosmopolitan; distributed across all ecosystems such as lakes, pools, reservoirs, hill streams, rivers, estuaries and the oceanic compartments (Cloern et al. 2014). Ecological studies emphasizing on phytoplankton and zooplankton communities has been exhaustively studied at recent times since there is a vivid environmental influence on the planktonic communities (Thabet et al. 2018). Tropical estuarine ecosystems in this respect are fascinating for studying the dynamics of zooplankton, due to its frequently changing hydrological conditions and rigorous biological processes (Islam et al. 2006). Zooplankton communities play a pivotal role in the functioning of aquatic ecosystems as it provides crucial linkages in the aquatic food web (Capriulo et al. 2002; Sotton et al. 2014). The information regarding the abundance and composition, and its relationship with the environmental parameters is indispensable for understanding the ecological processes of a particular area (Sousa et al. 2008). Monitoring and understanding the alterations in the dynamics of the zooplankton community over time can also provide a deep insight about the ecosystem functioning, which forms the basis for developing predictive models based on natural and anthropogenic alterations in the environment, especially those induced by climate variations (Tommasi et al. 2013). Therefore, it is imperative to study spatial and temporal structure of the zooplankton community to comprehend the state of ecosystem health.

Tidal creeks are a pre-eminent part of the estuarine ecosystem. These are extensive, bountiful and home to enormous biodiversity (Mallin 2004). They are highly fecund coastal environments in terms of aquatic biodiversity (Wiegert and Freeman 1990), acting as a support system to complex food webs (Posey et al. 2002). They also serve as feeding and nursery grounds, providing food and habitat to numerous fish, and other species of commercial importance (Lawal-Are et al. 2010). Several estuaries across the world have numerous tidal creeks with diverse water quality characteristics which pilot the ecosystem functions (Lerberg et al. 2000). Off late, the increased efforts to develop coastal areas for various economic purposes have resulted in the tidal creeks losing their ecological value (Vernberg and Vernberg 2001). Anthropogenic effluents such as nutrients, pesticides, heavy metals and other chemical pollutants contaminate the creek waters to a dangerous level (DeLorenzo et al. 2001). The net result is that many of these productive and ecologically significant ecosystems are degraded to various extents. Thus, these ecosystems are highly susceptible to environmental changes and human induced changes; nevertheless, their ecological significance is underestimated which is reflected by the fact that significantly a smaller number of studies have been conducted on these systems as compared to other known estuarine systems (Mallin 2004).

The Delta of Hooghly - Matla estuarine system is traversed by seven major rivers along with their tributaries and creeks. This deltaic system harbours luxuriant mangroves, and constitutes Sundarban mangrove ecosystem, which is one of the most biologically productive ecosystems. The Indian Sundarban Delta (ISD) is experiencing the adverse impacts of climate change, such as sea level rise, changes in temperature, precipitation regime, and cyclone activity since last three decades (Danda et al. 2011). As per the Delta Vision document of WWF - I, Sagar Island is one of the most vulnerable areas of ISD archipelago (Danda et al. 2011). The estimated sea level rise along the coast of Sagar Island was found to be $3.14 \mathrm{~mm} / \mathrm{year}$ which was attributed to global warming and other local factors (Hazra et al. 2002). The Sagar island is bestowed with 12 major creeks and numerous minor creeks forming a web of intertidal creeks with luxuriant vegetation, and biodiversity that includes various planktonic, nektonic forms (Sarkar 1983). Among these, the zooplankton community structure encountered in the Hooghly estuary is of considerable interest, because it has direct cascading impact on the higher trophic levels in the aquatic trophic guild (Sarkar 1983). Information with respect to the zooplankton in Indian Sundarbans is mostly limited to rivers (Nandy et al. 2018; Nandy and Mandal 2020; Paul et al. 2019), and north east part of the Indian Sundarbans (Bhattacharyya et al. 2015), whereas the studies on zooplankton from the tidal creeks of Indian Sundarban as well as other tropical creek systems are scarce (Sarkar et al. 1985 and 1986). Hence, the present study was undertaken to analyze the zooplankton community assemblage and its distribution concerning environmental variables in the tidal creeks of Indian Sundarban ecoregion. The alternate hypothesis is that the different environmental parameters along the tidal creeks have influence on the structure and compositions of the zooplankton community assemblage over a seasonal period.

\section{Materials And Methods}

\section{Study area}

Sagar Island is the largest inhabited island in the Indian Sundarbans ecoregion, lying between latitude $21^{\circ} 37^{\prime}$ and $21^{\circ} 52 区 \mathrm{~N}$ and longitude $88^{\circ} 03^{\prime}$ and $88^{\circ} 11^{\prime}$ $\mathrm{E}$ in the western part of the Hooghly-Matlah estuarine system. The island is traversed by large and small tidal creeks which are connected with the open 
estuarine water. In the present study, the sampling sites were chosen based on the varying hydrographical conditions and anthropogenic interference, which includes fishing, agriculture and other commercial activities etc. Six sampling sites viz., Sikarpur (SIK), Sagar (SAG), Hatipeta (HAT), Chemaguri (CHE), Phooldubi (PHO) and Kachuberia (KAC) (hereafter referred to as S1, S2, S3, S4, S5 and S6, respectively) were selected on the six major creeks. Station S1 and S4 opens into Mooriganga river, and S3, S5 and S6 opens into river Hooghly, whereas S2 opens into the Bay of Bengal. The study period is considered as post-monsoon (November to February), characterized by low to negligible rainfall and low temperature; pre-monsoon (March to June) characterized by squalls and convectional rainfall and high temperature, and Monsoon (July to October) characterised by torrential rains with sultry weather conditions (Chaudhuri et al. 2012). The geographical locations of the sampling sites and study area are shown in Fig. 1.

\section{Sampling methodology}

Monthly sampling was carried out from six sampling stations between July 2016 and June 2018 . For determination of water quality, sub-surface water samples ( $0.5 \mathrm{~m}$ depth) were collected using Niskin water sampler and transferred immediately to pre-rinsed polyethylene bottle ( $1.0 \mathrm{~L})$. Water samples were brought to the laboratory in cold condition for further nutrients analysis. We obtained in situ measurements of water temperature (Temp.) by a mercury thermometer ( $\mathrm{P}-601466), \mathrm{pH}$ with a digital pH meter ( $\mathrm{pH}$ 620, Eutech Instruments, Singapore) and turbidity (Nephelometric turbidity unit) was measured by a Turbidity meter (Model No. El331E). The salinity, dissolved oxygen (DO) and total alkalinity (TA) were estimated on board by following titrimetric methods (APHA, 2012). The water samples collected for dissolved nutrient analysis were filtered through GF/F filter paper (mesh size-0.7 $\mu \mathrm{m}$ ) for removing the particulate matter and the filtrate was stored at $-20^{\circ} \mathrm{C}$ until further analysis. Nutrients such as nitrite $\left(\mathrm{NO}_{2}-\mathrm{N}\right)$, nitrate $\left(\mathrm{NO}_{3}-\mathrm{N}\right)$, phosphate $\left(\mathrm{PO} \mathrm{O}_{4}-\mathrm{P}\right)$ and silicate $\left(\mathrm{SiO}_{4}-\mathrm{Si}\right)$ were analysed following standard spectrophotometric procedures described in Strickland and Parsons (1972). For analysis of biochemical oxygen demand (BOD), water samples were collected separately in $500 \mathrm{ml}$ polyethylene bottles (HDPE, Tarson). BOD was estimated by 5 -day BOD test (APHA 2005). All the methods were standardized as per ambient conditions, and blank measurements were taken into consideration for the procedures.

Zooplankton samples were collected by filtering $100 \mathrm{~L}$ of water through $50 \mu \mathrm{m}$ plankton net (mouth diameter: $75 \mathrm{~cm}$ ) from the sampling sites. To avoid the large-scale variation in zooplankton and dial vertical migration, all the samples were collected during morning hours between 6.00 am to 10.00 am. The collected samples were preserved in $4 \%$ buffered formalin and transported to the laboratory at the earliest for qualitative and quantitative analysis. A total of 144 zooplankton samples were analysed in the present study. The Sedgewick-Rafter counting cell method was applied for enumeration of zooplankton by employing trinocular light microscope (Axioster plus - Carl Zeiss). The taxonomic composition of the samples was analysed to the lowest possible taxa following standard taxonomic identification keys (Kasturirangan 1963; Conway et al. 2003; Al-Yamani et al. 2011; Shiel 1995). The abundance of zooplankton was expressed as number of individuals per cubic meter (ind. $\mathrm{m}^{-3}$ ).

\section{Data analysis}

The water quality parameters were normalized by transforming $\log (x+1)$ except $\mathrm{pH}$ prior to analyses. The water quality parameters in different stations were subjected to one-way analysis of variance (ANOVA), and Post hoc test (Duncan's multiple range tests) using SPSS v.21. The statistical significance of spatio-temporal differences of water variables were tested with a Permutational Multivariate Analysis of Variance (PERMANOVA), a non-parametric multivariate statistical test. Pearson's correlations (2-tailed) between water variables and zooplankton groups, and between the copepod families were also computed. ANOVA (post hoc) was performed to understand the significant variations of copepod families in seasons. Further, we performed the PERMANOVA to test the differences $(p \leq 0.05)$ between the zooplankton samples (abundance) in terms of seasons and stations. Alpha diversity ( $\mathrm{a}$-diversity)

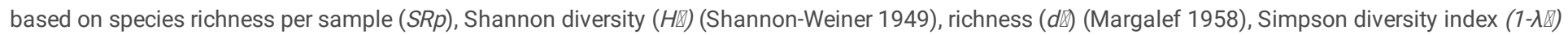
(Simpson 1949) and Evenness index (Pielou 1977) were measured. Additionally, one-way ANOVA was performed to identify the significant ( $p \leq 0.05$ ) differences of the richness of zooplankton taxa across stations. Beta $(\beta)$ diversity was measured using two multivariate approach viz., index of multivariate dispersion (MVDISP; Warwick and Clarke 1993), and $\beta$-dissimilarity index based on Bray curtis dissimilarity (Bray Curtis 1957). The index of multivariate dispersion (IMD) was also applied as a multivariate stability index to evaluate the stability changes in the zooplankton community (Warwick and Clarke 1993). The graphical representation of $k$-dominance curve in both the year was employed to investigate the dominance pattern of zooplankton taxa across seasons. A Bray-Curtis similarity matrix was then calculated in the six stations sampled during the different phases. Cluster analysis (group averaged) and multi-dimensional scaling (MDS) were used to assess the similarity of community structure among samples; which were then tested using analysis of similarity (ANOSIM) to understand the significant differences between stations with respect to zooplankton species composition.

Similarity percentage (SIMPER) routine was performed to categorize species responsible for similarity (characterizing species) and dissimilarity (discriminating species) between the groups, and also the relative contribution of individual species to the total zooplankton community. RELATE test, a nonparametric type of Mantel test, was performed to comprehend the significant pattern of the change of the zooplankton species assemblage between the two years (2016-17 and 2017-18). Pre-treatment of all the biological data was done by square root transformation to achieve the normality of the zooplankton abundance data. To identify and quantify the environmental variables that influenced the zooplankton community variability, BIO-ENV (Biota and/or Environment matching) and the distance - based linear model (DistLM) were conducted. BIO-ENV procedure reflected the best set of environmental variables that explained the patterns of zooplankton communities. A marginal test (non-parametric significance test), was used to determine the variation in biological data, and each environmental variable that can explain. Further, sequential test was done to examine whether any particular variable contributed significantly to the explained variation in biological (zooplankton) data (Clarke et al. 2014). The fitted DistLM was visualized using the distance-based redundancy analysis (dbRDA). Then we obtained the model using the Akaike information criterion (AICc), and the stepwise selection procedure. The above stated analyses were performed by using PRIMER v 6.0 (Clarke and Gorley 2006).

\section{Results}


The variations of water quality variables in different seasons of the study sites are shown in Table 1. No significant spatial differences ( $p \geq 0.05)$ in water variables were found, while the temporal differences exhibited significant heterogeneity (ANOVA post hoc test, $p \leq 0.05$ ). Out of 11 water parameters, seven parameters (Temp., salinity, DO, turbidity, $\mathrm{PO}_{4}-\mathrm{P}_{1} \mathrm{NO}_{3}-\mathrm{N}$ and $\mathrm{NO}_{2}-\mathrm{N}$ ) differed significantly $(p \leq 0.05)$ among seasons. The creeks water remained alkaline throughout the study period. Lowest pH was observed at S1 (6.51), and highest at S6 (8.2) throughout the sampling period. Seasonal mean surface water temperature ranged from $20.06 \pm 3.48^{\circ} \mathrm{C}$ to $31.0 \pm 2.41^{\circ} \mathrm{C}$. The highest $\left(32.70^{\circ} \mathrm{C}\right)$ and lowest $\left(16.9^{\circ} \mathrm{C}\right)$ value was recorded at S1 in June and S6 in January, respectively. A wide variation of salinity was observed during the study period. The maximum salinity was recorded at S2 in June (27.2 ppt), and lowest at $\mathrm{S} 5$ in September (0.60 ppt). The salinity values varied at the different sampling stations according to their distance from the sea. Differences in dissolved oxygen concentration of the stations were found to be no significant. The higher magnitude of dissolved oxygen was obtained during post-monsoon

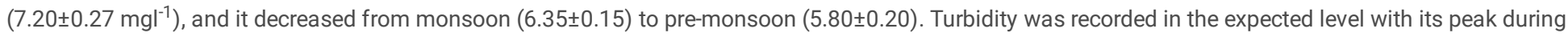
monsoon and lowest in pre-monsoon. Mean seasonal turbidity varied from $23.35 \pm 14.48$ to $88.63 \pm 16.25$ NTU with its maximum (104.0 NTU) at S6 in October, and minimum (12.0 NTU) at S3 in January.

The seasonal trend of nutrients was not uniform in the studied stations. $\mathrm{NO}_{3}-\mathrm{N}$ contents were comparatively higher during monsoon, and its concentrations were recorded maximum at $\mathrm{S} 6$ and minimum at $\mathrm{S} 1$. A similar type of seasonal trend was noticed for dissolved $\mathrm{PO}_{4}-\mathrm{P}$ and $\mathrm{NO}_{2}-\mathrm{N}$ in the sampling sites. The mean concentrations of $\mathrm{PO}_{4}-\mathrm{P}$ and $\mathrm{NO}_{2}-\mathrm{N}$ were found to be decreasing from monsoon to post-monsoon, and again it started showing reverse trend during pre-monsoon. Dissolved $\mathrm{SiO}_{4}-\mathrm{Si}$ exhibited wide variation across seasons; however, post hoc analysis portrayed no significant difference ( $p \geq 0.05$ ) among stations. Though ANOVA (post hoc test) portrayed no significant variations of water variables across the stations; PERMANOVA analysis reflected the significant spatial $(F=1.459, p=0.046)$ and temporal $(F=7.923, p=0.001)$ differences in water variables in the studies creeks. Intra-relationship among various water quality parameters is described in Table 2 . Water temperature exhibited significant positive correlation with turbidity $(r=0.682 ; p \leq 0.01)$, $\mathrm{PO}_{4}-\mathrm{P}(\mathrm{r}=0.535 ; p \leq 0.05)$ and $\mathrm{NO}_{3}-\mathrm{N}(\mathrm{r}=0.575 ; p \leq 0.05)$. Salinity in turn, was found to have a correlation with nutrient parameters viz., $\mathrm{PO}-\mathrm{P}(\mathrm{r}=0.443)$, $\mathrm{NO}_{3}-\mathrm{N}(\mathrm{r}=-0.50 ; p \leq 0.05)$ and $\mathrm{SiO}_{4}-\mathrm{Si}(\mathrm{r}=0.75 ; p \leq 0.01)$. DO also had significant negative correlation with turbidity $(\mathrm{r}=-0.601 ; p \leq 0.01), \mathrm{PO}-\mathrm{P}(\mathrm{r}=-$ $0.723 ; p \leq 0.01)$ and $\mathrm{SiO}_{4}-\mathrm{Si}(r=-0.591 ; p \leq 0.01)$ during the study period.

\section{Zooplankton abundance, composition and distribution}

The mean abundance of total zooplankton and copepod population in the studied stations are given in Table 3. A total of sixty three zooplankton taxa were recorded throughout the study period. Among zooplankton major groups, Copepoda was most prominent in terms of species richness and numerical abundance, varying in ranges from 59.55 to $73.13 \%$ of the total zooplankton. Among zooplankton Calanoida alone contributed $46 \%$ followed by Cyclopoida (15\%) and Harpacticoida (6\%). The other groups contributing significantly were larvae (13\%), crustacean nauplii (9\%) and Mysids (4\%) (Fig. 2). The mean seasonal abundance was maximum during the pre-monsoon $\left(50,861.11 \pm 23,702.63\right.$ ind. $\left.\mathrm{m}^{-3}\right)$ and lowest in the monsoon $\left(29,805.56 \pm 17,571.72\right.$ ind. $\left.\mathrm{m}^{-3}\right)$. On the whole, the quantitative spectrum of total zooplankton ranged from 10,000 to 1,10,000 ind. $\mathrm{m}^{-3}$ with its maximum abundance at $\mathrm{S} 1$ and minimum at $\mathrm{S} 5$ during February and October, respectively. The station-wise average numerical abundance of zooplankton in different seasons is illustrated in Fig. 3 . As a whole, holoplankters dominated throughout the study period in all the stations contributing $71.4-87.9 \%$ to the total zooplankton community with the highest in monsoon and lowest in pre-monsoon. The meroplankters contributed $11.2-34.62 \%$ to the total zooplankton density with the highest in pre-monsoon and lowest in monsoon. The abundance of holoplankters and meroplankters in the different stations are shown in Fig. 4 (a \& b).

A total of 41 species of Copepoda were recorded throughout the study comprising 30 species of Calanoida (14 genera), 5 species of Cyclopoida ( 3 genera) and 6 species of Harpecticoida ( 5 genera). The family Paracalanidae and Oithonidae invariably constituted the bulk of the total copepod population, and accounted for $41 \%$ and $17 \%$ respectively. Maximum species diversity that was recorded belonged to the families of Paracalanidae (7) followed by Acartiidae (5) and Pseudodiaptomidae (4). Out of 41 species of Copepoda recorded, 14 species (Paracalanous parvus, Parvocalanous dubia, Bestiolina similis, Acrocalanous gibber, A. gracilis, Acartia erythrea, A. spinicauda, Psudodiaptomus serricaudatus, P. annandalei, P. aurivilli, Oithona brevicornis, O. similis, Longipedia weberi and Microsetella norvegica) were perennially present in the creeks. That in turn, clearly highlights the euryhaline nature, and broad range of thermal tolerance of these species. The average numerical abundance of Copepoda was maximum during pre-monsoon $\left(31,791 \pm 7,012\right.$ ind. $\left.\mathrm{m}^{-3}\right)$ followed by post-monsoon $\left(29,152 \pm 5,597\right.$ ind. $\left.\mathrm{m}^{-3}\right)$ and monsoon $\left(19,236 \pm 5,912\right.$ ind. $\left.\mathrm{m}^{-3}\right)$. The mean percentage contribution of Copepoda was highest at $\mathrm{S} 5(73 \%)$ and lowest at S2 (65\%), whereas month-wise, it accounted maximum during May (74\%). The correlation coefficient values of the family Paracalanidae, Acartiidae, Eucalanidae, Temoridae and Calanidae showed positive correlation between them, explaining the possible formation of groups by themselves (Table 4). Out of 17 copepod families, six families (Paracalanidae, Acartiidae, Temoridae, Calanidae, Oithonidae and Oncaeidae) differed significantly (ANOVA; $p \leq 0.05$ ) between seasons, while rest of the families did not portray significant temporal variations.

Albeit, Copepoda can be considered as the major group, which comprised of a large proportion of total zooplankton population in all the months, the occasional co-dominance of larvae (comprising of the polychaete, cirripede, isopod, amphipod, gastropod and fish larvae) and mysids were also documented. The mean abundance of larvae was maximum during pre-monsoon $\left(6,222\right.$ ind. $\left.\mathrm{m}^{-3}\right)$ and minimum in monsoon $\left(2,500\right.$ ind. $\left.\mathrm{m}^{-3}\right)$. Throughout the study period, the numerical abundance of larvae was maximum in October and minimum in July. Rotifera and Cladocera contributed $1 \%$ each to the total zooplankton throughout the study period. The temporal abundance of Rotifera exhibited two peaks (bi-modal pattern) in August and November. There was significant increase in average numerical abundance of Rotifera from pre-monsoon ( 55 ind. $\left.\mathrm{m}^{-3}\right)$ to post-monsoon (430 ind. $\left.\mathrm{m}^{-3}\right)$. Cladocera did not vary significantly across the seasons. Chaetognatha was represented by a single species, Zonosagitta bedoti with an average numerical abundance of 386 ind. $\mathrm{m}^{-3}$, and exhibited its maximum (1,505 ind. $\left.\mathrm{m}^{-3}\right)$ in January. Its abundance exhibited unimodal pattern across the seasons. Among the others, Mysids contributed significantly to the total zooplankton density, whereas Hydromedusae were spotted sporadically during the study period. Results of ANOVA (post 
hoc test) showed, no significant spatial differences in zooplankton (groups), while temporal differences exhibited significant heterogeneity ( $p \leq 0.05$ ) among the zooplankton groups such as Copepoda ( $F=4.061 ; p=0.039)$, Cladocera $(F=7.046 ; p=0.007)$, Chaetognatha $(F=3.902 ; p=0.05)$, crustacean nauplii $(F=13.442 ; p=0.001)$ and larvae $(F=7.902 ; p=0.005)$. Other three major groups viz. Rotifera $(F=1.214 ; p=0.324)$, Eggs $(F=1.220 ; p=0.323)$ and Mysids $(F=1.73 ; p=0.930)$ did not show statistically significant variations across seasons.

\section{Species similarity}

The Cluster analysis on the similarity of zooplankton species abundance in the studied stations are shown in Fig. 5. The species abundance resulted in three clusters. The maximum similarity (83.9\%) was observed between the stations S1 and S2 during post-monsoon, and lowest similarity (73\%) between S3 and S6 during pre-monsoon. On the whole, the species composition in the samples exhibited $>65 \%$ similarity between the stations. The grouping of species composition was further substantiated by the NMDS, and the plot also gave similar compositional pattern among samples. The assemblage of pre-monsoon differed substantially from that of the other two seasons, with regard to the zooplankton composition (Fig. 6). Results of ANOSIM reflected the significant (Global $\mathrm{R}=0.101$; significance level $0.1 \%$ ) spatial differences of zooplankton species composition. The zooplankton community also depicted the significant temporal variation ( $\mathrm{R}=0.565$; P $0.1 \%$ ). The $k$-dominance curve extracted for the period $2016-17$ reflected that the species abundance and diversity was noticeably higher during the pre-monsoon as compared to the other seasons (Fig. 7a), whereas in the following year (2017-18) the curves overlapped indicating no differences in the species diversity, illustrating the similar dominance patterns (Fig.7b). RELATE routine analysis further substantiated the significant $(\rho=0.399 ; \mathrm{P} 0.1 \%)$ inter annual differences of the zooplankton community compositions between $1^{\text {st }}$ and $2^{\text {nd }}$ year study period. Though, one-way ANOVA (post hoc) results portrayed no significant variation of the zooplankton groups spatially ( $p>0.05$ ), PERMANOVA design depicted the significant variations of zooplankton population both spatially $(F=2.313 ; p=0.001)$ and seasonally $(F=6.107 ; p=0.001)$. On the whole, the spatio-temporal variations of zooplankton were found to be significant $(F=2.0 ; p=0.001)$ in the study area.

SIMPER routine was analysed based on the abundance of zooplankton described the characterizing species (within the group similarity), and discriminating species (between the group dissimilarity). The average similarity percentage varied between 44.69 and $51.1 \%$ with the highest at S3 and lowest at S6. Table 5 summarizes the information on characterizing species and their percentage contribution to the total zooplankton abundance in each group. At $\mathrm{S} 3, P$. parvus (12.4\%), B. simils (10.9\%), O. brevicornis (9.76\%) and P. dubia (9.70\%) were most prominent. Similarly, B. similis (20.34\%), O. brevicornis (9.84\%), P. parvus (8.55\%) and A. spinicauda (7.07\%) were the main contributors at the station $\mathrm{S6}$. The dissimilarity percentage calculated ranged from 50.34 to $56.81 \%$ with the highest percentage found to be between S2 and S6 (56.81\%). Paracalanous parvus (6.20\%), crustacean nauplii (5.65\%), polychaete larvae (5.60\%), O. brevicornis (5.34\%), B. similis (3.89\%), P. dubia (3.28\%), Longipedia weberi (3.23\%) and Acrocalanous gibber (3\%) were the major contributors to this group. With that of percentage contribution ( $\beta$-dissimilarity) in the different assemblages, these species exhibited as key zooplankton species that differentiated between the assemblage, and their variability makes them discriminating species in the different zooplankton assemblages.

\section{Diversity indices}

\section{a-diversity}

The occurrence of Copepoda species varied considerably in seasons. Maximum species richness (36 species) was recorded at the station S3 during pre-monsoon followed by S2 (34 species) and S5 (32 species) during post-monsoon and pre-monsoon, respectively. The average species richness of the Copepoda was $28 \pm 4$ species across the stations. On the whole, the seasonal species richness was highest during pre-monsoon ( 41 species) followed by monsoon (37 species) and post-monsoon (31species) throughout the study period. In respect of total zooplankton, maximum richness was accounted for 53 taxa at S2 during post-monsoon, whereas it was minimum at S4 (34 taxa) during monsoon. Significant spatial variations in the zooplankton taxa during monsoon $(F=5.667 ; p=0.000)$ and post-monsoon $(F=9.634 ; p=0.000)$ was observed, whereas the variation was not significant during pre-monsoon $(F=$ $1.474 ; p=0.219)$.

The Shannon-Wiener diversity $\left(H^{\prime}\right)$, Margalef's species richness $(d \mathbb{Z})$ and Pielou's evenness index $(J \mathbb{V})$ in the studied stations for both the year is shown in Fig. 8. As with total zooplankton population, the $d \mathbb{Z}$ was highest at S1 during post-monsoon (5.47) and lowest at S5 during monsoon (2.55). The $H \mathbb{V}$ values also depicted similar trend with the maximum at S1 during post-monsoon (2.71) and minimum at S2 during monsoon (1.66). The stations S1 and S6 showed similar assemblage pattern with regard to the richness, evenness and diversity of zooplankton. Throughout the study period, the zooplankton assemblage was not uniformly distributed in the studied stations and fluctuated greatly. The zooplankton species evenness (JW) depicted that, it was relatively higher at S4 during pre-monsoon (0.86) and lower at S5 during monsoon (0.55). Results of ANOVA (post hoc test) showed significant variations ( $p \leq 0.05$ ) of diversity

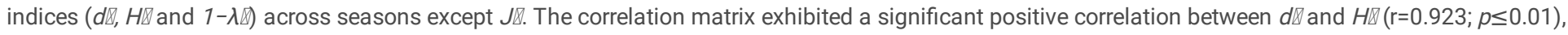

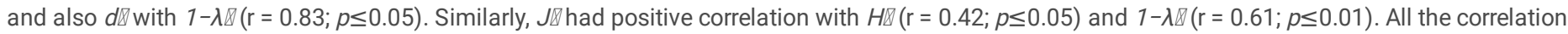
coefficient values of the indices showed positive correlation between them, implying similar pattern of species interaction in the zooplankton assemblage throughout the study.

\section{$\boldsymbol{\beta}$ - diversity}

The relative dispersion (inter stations $\beta$-dissimilarity) value calculated using the multivariate dispersion index. The stations S4 (=1.11), S2 (=1.13) and S6 $(=1.16)$ showed higher values $(>1)$ indicating high $\beta$-diversity compared to S3 $(=0.72)$ and S5 $(=0.77)$. The zooplankton species turnover was registered in the impacted stations (S4, S2 and S6) as the values reached $\beta=1$. However, the pair-wise comparison (stations compared) of IMD depicted lower values $(<1.0)$ indicating community variability (stability) during the study period. The $\beta$-dissimilarity index revealed the inter-stations differences in the species distribution patterns in the study area. The highest $\beta$-dissimilarity percentage was found to be between S2 and S6 with $56.81 \%$ and lowest between S3 and S5 (50.34\%). 
The correlation matrix showed that, Copepoda was positively correlated with salinity $(r=0.557 ; p \leq 0.05)$, DO $(r=0.46)$, and negatively correlated with $\mathrm{NO}_{3}-\mathrm{N}$ $(r=-0.479 ; p \leq 0.05)$. Cladocera had positive correlation with salinity $(r=0.367)$, and significant negative correlation with turbidity $(r=-0.60 ; p \leq 0.01)$. Crustacean nauplii and larvae also portrayed significant positive correlation with the salinity, $\mathrm{PO}_{4}-\mathrm{P}$ and $\mathrm{SiO}_{4}-\mathrm{Si}$, and negative correlation with $\mathrm{DO}$, turbidity and $\mathrm{NO}_{3}-\mathrm{N}$ (Table 2). By and large, total zooplankton displayed the significant positive correlation with salinity $(r=0.617 ; p \leq 0.05)$, and negative correlation with $\mathrm{NO}_{3}-\mathrm{N}(\mathrm{r}=-0.575 ; p \leq 0.05)$.

For all the sampling stations, the correlation between zooplankton abundances and environmental variables were established by multivariate BIOENV analysis. The analysis confirms a set of environmental parameters that is related to spatial variations of zooplankton. BIO-ENV analysis (employing Spearman rank correlation method) reflected that the water quality parameters viz., $\mathrm{pH}$, salinity, $\mathrm{DO}$, turbidity, $\mathrm{PO}_{4}-\mathrm{P}, \mathrm{NO}_{3}-\mathrm{N}$ were correlated with the zooplankton community (Table 6). The best set of correlation between zooplankton and the individual environmental variable obtained in the combination of salinity and $\mathrm{PO}_{4}-\mathrm{P}$ with the maximum coefficient of 0.210 , whereas the minimum correlation coefficient $(0.170)$ was recorded only with salinity. The correlation coefficient $(\rho=0.21)$ with the significance level $1.6 \%$ indicated that, two variables $i$. e. salinity and $\mathrm{PO}_{4}-\mathrm{P}$ were the controlling factors for the distribution of zooplankton in the studied stations. To quantify the additional explained variables, Marginal tests (distance based linear model, DistLM) was performed to obtain a significant correlation between the zooplankton and each of the environmental variables. The results showed that, the significance correlation $(p \leq 0.05)$ has been observed, with the variables such as Temp., salinity, DO, turbidity, $\mathrm{PO}_{4}-\mathrm{P}$ and $\mathrm{NO}_{3}-\mathrm{N}$. The Sequential tests also revealed similar results with the former having significant correlation $(p \leq 0.05)$ with three variables viz., Temp., salinity and turbidity (Table 7$)$. The fitted model (DistLM) explained that the two variables; Temp. and salinity were the deterministic parameters to explain the zooplankton community compositions in the studied stations (Table 8).

\section{Discussion}

\section{Zooplankton community structure and its distribution pattem}

The density and taxonomic diversity of the organisms in samples is primarily dependent upon the mesh size of sampling nets (Turner and Dagg 1983). The abundance of zooplankton, particularly the copepod nauplii and small copepods (Oithona spp.) were undervalued by the use of large mesh nets for sampling. For example, a mesh size of $>150 \mu \mathrm{m}$ is fairly large to sample quantitatively the small copepods and meroplankters, that sometimes dominate the estuarine zooplankton community (Fulton 1984). In our study, overall, the copepod nauplii and juvenile stages of copepods accounted great majority in the samples. While profiling the zooplankton taxa in the creeks of Sagar Island, Sundarbans, a total of 63 zooplankton taxa were documented. Bhattachajee et al. (2015) reported 41 meso-zooplankton taxa from the northern part of Sundarban mangrove wetland; 56 zooplankton taxa from the river Saptamukhi, Sundarban estuarine system (SES) (Nandy et al. 2018), and 47 taxa of zooplankton from Mooriganga river estuary reported by Paul et al. (2019). Recently, Nandy and Mandal (2020) documented 56 zooplankton taxa from river Matlah, Sundarban estuarine system, primarily dominated by Copepoda.

The dominance of Copepoda in the zooplankton community was well documented in various estuaries across the world in both tropical and temperate regions (Mwaluma et al. 2003; Gao et al. 2008; Bhattacharyya et al. 2015; Srichandan et al. 2015; Abdul et al. 2016; Paturej et al. 2017; Nandy et al. 2018). During the present study, Copepoda contribution to the total zooplankton population was ranging from 59.5 to $73.13 \%$, which was in line with the findings of Nandy and Mandal (2020) from Matlah river system, where the authors reported the dominance of Copepoda (59 to $87 \%$ ) to the total zooplankton population with the monsoon maxima (87\%). However, in the present context, a pre-monsoon maximum was evident, which was contrast to the observations made by Nandy and Mandal (2020), but in agreement with the other workers (Ramaiah et al. 1996; Bhattacharya et al. 2015). The recruitment of neritic species through tidal influenced massive ingress of seawater into the creeks also could be one of the plausible causes for higher abundance of Copepoda in pre-monsoon (Mishra and Panigrahy 1996). Sarkar et al. (1986) found predominance of Copepoda (73-96\%) in the total zooplankton population with highest values in pre-monsoon, and lowest during late monsoon period in the creeks of Sagar Island which supports the findings of the present study. Calanoid copepods being the dominant group followed by Cyclopoids and Harpacticoids during pre-monsoon in the present study was in line with Bhattacharya et al. (2015). Sai Sastry and Chandramohan (1995) also reported similar kind of Copepods contribution viz., Calanoid > Cyclopoid > Harpacticoid during pre-monsoon with herbivorous and omnivorous copepods being the principal trophic components in the Cochin backwaters (Madhu et al. 2007). The abundance of Copepoda steadily increased from post-monsoon to pre-monsoon with rising trend of the salinity in the present study. The recorded low zooplankton abundance during monsoon could be attributed to heavy influx of freshwater coupled with abrupt hydrological changes, which in turn decreased the zooplankton density (Mwaluma et al. 2003; Santhanam et al. 2012).

Community structure of zooplankton in the present study was in conformity with the Varghese and Krishnan (2009); Bhattacharya et al. (2015) and Rakesh et al. (2013), where the authors noted higher zooplankton species composition during pre-monsoon as compared to other seasons. The ubiquitous dominance of Copepod species viz. B. similis, P. parvus, P. dubia, A. spinicauda, P. serricaudatus, $O$. brevicornis and $O$. similis in the creeks habitat signifies their broad trophic spectrum (Nandy and Mandal 2020) with high adaptability to the environmental conditions. In the present study, 14 Copepod species has been documented as having perennial existence in the studied creeks, which may be due to their continuous breeding nature, high reproductive capacity coupled with suitable environmental conditions and food availability in the ecosystem (Ramaiah and Nair 1997; Santhanam and Perumal 2003). Similar type of species dominance has been reported from Mandovi and Zuari estuarine system and Godavari estuary by Padmavathi and Goswami (1996) and Sai Sastry and Chandramohan (1995), respectively. The dominance of Copepod families viz., Oithonidae, Paracalanidae, Acartiidae and Pseudodiaptomidae in the present study were at par with the findings of Neumann-Leitao et al. (1992); McKinnon and Klumpp (1998). The higher abundance of species Acartia sewelli, Eucalanus crassus, Candacia bradyi, Acrocalanous longicornis during pre-monsoon, and A. plumosa, Centropages dorsipinnatus during post-monsoon, probably explains the limited period of existence, and highlighting the temporal shift in species abundance in the creeks of Sundarbans. The 
prevalence of high numbers of Oithona spp. among other copepods in the present results was similar to the reports of Gallienne and Robins (2001), which described them as the most abundant and ubiquitous copepod in the world. High abundance of Oithona spp. in the zooplankton population could be attributed to their smaller body size, omnivorous feeding habit (Kumar 2003), and high reproductive capacity (Santhanam and Perumal 2003). Almeda et al. (2010) suggested that the lower metabolic requirements of Oithonids compared to Calanoids might explain the high abundance of the former group, both in coastal eutrophic waters and in oligotrophic oceanic environment.

\section{Formation of groups and co-existence}

In the present study, the copepod families such as Paracalanidae, Candacidae, Oithonodae, Onceidae, Ectinosomatidae and Longipedidae showed positive correlation amongst themselves (Table 4) indicating that there is a close association between the families and species under these families can increase or decrease in conjunction with one another. Thus, it provides evidence that these families coexisted and combined to form their own group in the zooplankton assemblage. The coexistence of these copepods reveals their advantageous life history traits in the local environment (site-specific) which made them a successful inhabitant (Dur et al. 2007) in these creeks habitat. The families Candacidae and Tortanidae may have formed their own separate group, as they were both negatively correlated with most of the other families. Similar finding was also reported by Bhattacharya et al. (2015) from Sundarban waters, where the authors speculated that there is congeneric association of five and six species of family Acartiidae and Paracalanide, respectively, from Jambu Island, Indian Sundarbans. These coexisting species exhibited high adaptability and opportunistic nature, by means of shifting their feeding habit to adopt in a highly variable estuarine environment (Bhattacharya et al. 2015; Mwaluma et al. 2003).

Holoplankters predominated throughout the year in all the stations with slightly higher numbers in monsoon months, whereas meroplankters were highest during post-monsoon, which indicates a key role of salinity in controlling the zooplankton community (Jyothibabu and Madhu 2007). The co-dominance of meroplankters (polychaete larvae, decapod larvae, crab zoea, bivalvia, gastropod veliger, isopod larvae and cirripede larvae) is suggestive of the fact that these organisms take an important role in the coupling of bentho-pelagic food webs (Rakesh et al. 2008; Nandy and Mandal 2020). Another characteristic feature of the present observation was the relatively large occurrence of copepod nauplii, which could be attributed to high density of older copepods (Uye et al. 2000) round the year. Chaetognatha, Zonosagitta bedoti was found to be maximum during post-monsoon which was in consistent with the findings made by Nandy and Mandal (2020). Bhattacharya et al. (2015) reported higher percentage contribution of developing stages of $Z$. bedoti in their study from Sundarban mangrove wetland, and inferred that the species prefer estuarine environment for its development. In the present study, the mean abundance of Z. bedoti (386 ind. $\mathrm{m}^{3}$ ) was higher than the former study ( 55 ind. $\mathrm{m}^{3}$ ), which may be due to its salinity, geographic heterogeneity and sampling strategy. The gradual increase in the abundance of Chaetognaths from the post-monsoon to pre-monsoon season corresponding to the increase in salinity which was also reported by Sarkar et al. (1985) from Hooghly-Matlah estuarine system.

Significantly less contribution was made by Rotifera and Cladocera, which was often more specific to low saline water environment (Godhantaraman 2001), where they prevailed only during monsoon and late monsoon period. The occurrence of genera Brachionus and Ceriodaphnia during monsoon months indicates they are least tolerant to higher salinity, and transported passively by river run-off. In agreement to our study, similar observations have been made earlier by Govindasamy and Kannan (1991), where low abundance of Rotifera and Cladocera in the zooplankton community in Pichavaram mangroves was observed. The accumulation of meroplanktonic larval forms indicated the availability of rich food supply (planktonic forms) in the mangrove dominated creeks, low predation pressure (Kimmerer 1991), high growth rate (Turner 2004), and a balanced food concentration. In addition, these larval forms are also flushed by the sea during the spring tide, which also partially explains the neretic larval supply in the creeks. According to (Morgan 1995), the avoidance of predators may also influence the larval release and dispersal in the estuary, which could also be the reason for higher abundance of larvae, resting eggs and nauplii in the mangrove dominated creeks. The muddy substrate of the inner estuary supports a rich polychaete community, whose larvae were also more evident in the studied creeks.

\section{3. Creeks ecosystem health}

\section{Creeks ecosystem health}

Margalef's species richness $(d \mathbb{D})$ and Shannon-Wiener diversity $\left(H^{\prime}\right)$ exceeding 2.50 indicates healthy environment of an aquatic ecosystem (Magurran 1988). Similarly, Chao et al. (2009) categorized the threshold values of diversity index $(H \mathbb{V})$ for zooplankton in the tropical estuarine system as bad (<0.6), average (0.6-1.5), good (1.6-2.5), better (2.6-3.5), and excellent (>3.5). In the present investigation, the calculated mean value of $d \mathbb{V}$ and $H^{\prime}$ were found to be 4.07 \pm 0.45 and $2.31 \pm 0.15$ indicating 'good'zooplankton diversity in the creeks which was in conformity with Nandy and Mondal (2020) and Rakshit et al. (2015). The Index of multivariate dispersion showed higher values $(\beta=>1)$ in the creeks (S2, S4 and S6), those are experiencing high anthropogenic pressure coupled with other local factors (boat trafficking, dredging, tourism) in the present study. Seasonal mean diversity $(H \nabla=2.46)$ and richness $(d \nabla=4.44)$ values were maximum during post-monsoon along with high value of evenness index $(J \mathbb{V}=0.76)$. Similar results were also reported by Bhattacharya et al. (2015) where higher values of species diversity and richness during post-monsoon and lowest during monsoon were documented. Contrary to the present findings, Nandy and Mandal (2020) reported higher species diversity $(H \mathbb{V}=>1.6)$ and richness during pre-monsoon, but was of same view in reference to the monsoon minima. The species diversity decreases when a community become uneven, and is dominated by single species or fewer species (Rakshit et al.

2015). The value of $J \mathbb{Q}$ was $0.75 \pm 0.04$ for all the seasons, which implied evenly distribution of zooplankton population with the healthier diversity (Sun et al.

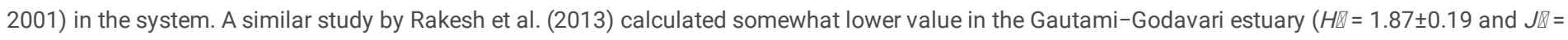
$0.59 \pm 0.01)$, and higher values $\left(H \mathbb{V}=2.62 \pm 0.25\right.$ and $J \mathbb{V}=0.79 \pm 0.008$ bits. ind. $\left.\mathrm{I}^{-1}\right)$ in coastal immediate waters.

\section{Correlation between zooplankton assemblage pattern and environmental traits}


The factors determining the seasonal and interannual variations of zooplankton assemblages are salinity, temperature, sediment type and origin of the fauna previously reported by Selifonovo (2008). The variations in the zooplankton community were significantly correlated to the physico-chemical factors (especially the water temperature, salinity, $\mathrm{DO}$, turbidity and $\mathrm{PO}_{4}-\mathrm{P}$ ) in the studied creeks. Abdul et al. (2016) ascribed that water variables (temperature, salinity, transparency and DO) significantly explain the principal variations in the zooplankton species composition in a Nigerian tropical coastal estuary, which was in line with the present observation. In estuarine environments, the salinity gradient has control over the overall species composition (Bollens et al. 2011). Therefore, a substantial positive correlation between salinity and various groups of zooplankton (Copepoda, Cladocera, Chaetognatha, crustacean nauplii, larvae, mysids and total zooplankton) were seen in the present study. This was at par with many other previous findings that emphasized the influence of salinity on zooplankton community (Paturej et al. 2009; Dube et al. 2010). However, the inversely proportional relationship between zooplankton density and salinity has been described from the Matlah system (Nandy and Mandal 2020), with a note that the predominance of low saline species of genus Paracalanus, Acartia and Acrocalanous are indicating the estuarine influence in their studies. In aquatic ecosystems the rise in temperature has been associated with elevated abundance and zooplankton species diversity (Buyurgan et al. 2010). The maximum density and diversity of zooplankton were recorded during pre-monsoon in the present study, which supports the notion. Furthermore, previous studies (Salvador and Bersano 2017; Du et al. 2020) noted that the increasing temperature promoted the abundance of small bodied copepods ( $P$. parvus and copepod nauplii in particular), which are frequently associated with the increase in temperature and eutrophic condition in the coastal environment. Our results also corroborated with the former findings where there was maximum abundance of small-bodied copepods (especially P. parvus, B. similis, $P$. dubia and $O$. brevicornis) during pre-monsoon season. This probably hinted towards the affinity for temperature, and increase in numerical abundance of zooplankton that could be directly proportional to the increasing temperature in the creek habitats. The relationship between zooplankton taxa, temperature and high concentrations of nutrients $\left(\mathrm{NO}_{3}-\mathrm{N}, \mathrm{PO}_{4}-\mathrm{P}\right.$ and $\mathrm{SiO}_{4}-\mathrm{Si}$ ) has been revealed by many studies (Park and Marshall 2000; Biancalana et al. 2014). It is consensus that an increase in the concentration of nutrients influences the top levels of a food web through a cascade of interactions (Anderson et al. 2002). The negative influence of $\mathrm{NO}_{3}-\mathrm{N}$ on the zooplankton community in the vistula lagoon (Paturej et al. 2017) was in agreement with the present observation.

Aquatic turbidity is also a causative factor in decreasing zooplankton and it accelerates copepod mortality, which was evident in Sundarban estuarine system (Nandy and Mandal 2020), and many other estuaries (Gordina et al. 2001; Park and Marshall 2000). In the present study too, turbidity negatively influenced on the zooplankton community. The mechanisms driving zooplankton community compositions are difficult to distinguish, but it is clear from the above discussion that water variables such as temperature, salinity, $\mathrm{DO}$, turbidity and $\mathrm{PO}_{4}-\mathrm{P}$ have profound influence on the zooplankton community structure in the creeks water, which was evident from the BIOENV and marginal test. Furthermore, the fitted model (DistLM) also depicted two variables viz., water temperature and salinity were the deterministic variables that could explain the distribution of zooplankton community. This is in agreement with previous studies which emphasized the impact of salinity and temperature on zooplankton distribution (Paturej et al. 2006; Gao et al. 2008; Sebastian et al. 2012). Additionally, the recruitment of zoobenthos populations in the creeks was largely ensured by the local populations, and their distributions and settlements are related to the tidal flow.

\section{Conclusion}

The present study reveals the spatio-temporal dynamics of zooplankton at various geographical locations stands unique, and provides a comprehensive information on the status of the ecological interaction with the zooplankton community in the creek environment. In the present investigation, the calculated

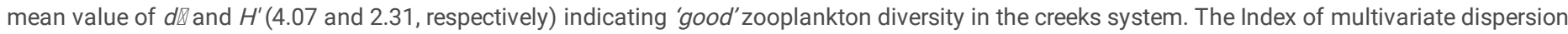
reflected higher values $(\beta=>1)$ in the creeks (S4, S2 and S6) that implied the systems are in stress due to varying anthropogenic pressure. Strong seasonal and spatial variations were recorded in the zooplankton community influenced by varying environmental variables. Temperature and salinity were positively correlated to the increase in zooplankton abundance. On the whole, water parameters such as temperature, salinity, $\mathrm{DO}$, turbidity and $\mathrm{PO}_{4}-\mathrm{P}$ and $\mathrm{NO}_{3}-\mathrm{N}$ were found to have influence on the distribution, abundance and diversity of zooplankton in the creeks. More specifically, among these variables, our fitted distance based linear model (DistLM) exhibited two variables viz., temperature and salinity were the principal factors in controlling the zooplankton community compositions in the creek environment. Overall, the study highlights the necessity of incorporating different approaches for a better understanding of zooplankton community structure in mangrove environment including Indian Sundarban ecoregion. The present work shall help in the ecological assessment of the creek ecosystem as well as providing the baseline information on tidal creek ecosystem.

\section{Declarations}

Ethical Statement: The authors declare that they have strictly followed all the rules and principles of ethical and professional conduct while completing the research work. No specific permission was required to collect the zooplankton samples at the study sites.

Consent to participate: Not applicable

Consent to publish: Not applicable

Conflict of Interest: The authors declare that they have no conflict of interest.

Availability of data: Data will be provided on request to the Corresponding author.

Funding Information: No financial support received from any organization, as the work was under Ph.D. research work. 
Sanghamitra Basu: Sample collection, taxonomic identification, statistical analysis, interpretation of data, manuscript preparation; Pranab Gogoi: taxonomic identification, statistical analysis and manuscript preparation; Subarna Bhattacharyya: Guidance, manuscript corrections; Lohith Kumar K.: Preparation of the map of the study area and manuscript preparation; Sanjoy Kumar Das: Manuscript preparation and corrections; Basanta Kumar Das: Overall guidance and correction.

\section{Acknowledgement}

First author is grateful to the Director, School of Environmental Studies, Jadavpur University, Kolkata -700032, India for providing laboratory support to carry out the research work. The first author also extends gratitude to the Director, ICAR-Central Inland Fisheries Research Institute, Barrackpore, Kolkata for providing facilities and guidance for the zooplankton sample analysis. The technical assistance received from the staffs of the School of Jadavpur University, associated with the laboratory activities are duly acknowledged.

\section{References}

1. APHA (2012) Standard methods for the examination of water and wastewater, in: (Eds). Rice, E.W., Baird, R.B., Eaton, A.D. and Clesceri, L.S. American Public Health Association (APHA), American Water Works Association (AWWA) and Water Environment Federation (WEF), 22nd edition, Washington, D.C., USA

2. Abdul WO, Adekoya EO, Ademolu KO, Omoniyi IT, Odulate DO, Akindokun TE, Olajidi AE (2016) The effects of environmental parameters on zooplankton assemblages in tropical coastal estuary, South-west, Nigeria. Egypt J Aquat Res 42(3):81-287

3. Almeda R, Augustin CB, Alcaraz M, Calbet A, Saiz E (2010) Feeding rates and gross growth efficiencies of larval developmental stages of Oithona davisae (Copepoda, Cyclopoida). J Exp Mar Biol Ecol 387(1 - 2): 24 - 35

4. Al-Yamani FY, Skryabin V, Gubanova A, Khvorov S, Prusova I (2011) Marine zooplankton practical guide. Kuwait Institute for Scientific Research, Kuwait, p 399

5. Anderson P, Westergren AS, Karlsson I, Hallberg R, Renvert S (2002) Oral health and nutritional status in a group of geriatric rehabilitation patients. Scand J Caring Sci 16(3):311-318

6. Bhattacharya BD, Hwang JS, Sarkar SK, Rakhsit D, Murugan K, Tseng LC (2015) Community structure of mesozooplankton in coastal waters of Sundarban mangrove wetland, India: a multivariate approach. J Mar Syst 141:112-121

7. Biancalana F, Dutto MS, Berasategui AA, Kopprio G, Hoffmeyer MS (2014) Mesozooplankton assemblages and their relationship with environmental variables: a study case in a disturbed bay. Environ Monit Assess 186(12):8629-8647

8. Bollens SM, Breckenridge JK, Vanden Hooff RC, Cordell JR (2011) Mesozooplankton of the lower San Francisco Estuary: spatio-temporal patterns, ENSO effects and the prevalence of non-indigenous species. J Plankton Res 33(9):1358-1377

9. Bray JR, Curtis JT (1957) An ordination of upland forest communities of southern Wisconsin. Ecological Monographs 27:325-349

10. Buyurgan O, Altindag A, Kaya M (2010) Zooplankton community structure of Asartepe dam lake (Ankara, Turkey). TrJFAS 10(1):135-138

11. Capriulo GM, Smith G, Troy R, Wikfors GH, Pellet J, Yarish C (2002) The planktonic food web structure of a temperate zone estuary, and its alteration due to eutrophication. Hydrobiologia 475/476:263-333

12. Chao CQ, Huang LM, Yin JQ (1994) Study on the diversity of zooplankters in Nansha Islands, Nansha Scientific exploration team of the Academy of Sciences of China. Ocean press, Beijing

13. Chaudhuri K, Manna S, Sarma KS, Naskar P, Bhattacharyya S, Bhattacharyya M (2012) Physico-chemical and biological factors controlling water column metabolism in Sundarbans estuary, India. Aquat Biosyst 8(1):26

14. Clarke KR, Gorley RN (2006) PRIMER v6: User manual/tutorial. PRIMER-E, Plymouth, 192 pp

15. Clarke KR, Gorley RN, Sommerfield PJ, Warwick RM (2014) Change in marine communities: and approach to statistical analysis and interpretation, 3rd edn. PRIMER - E, Plymouth

16. Cloern JE, Foster SQ, Kleckner AE (2014) Phytoplankton primary production in the world's estuarine-coastal ecosystems. Biogeosciences11(9):2477

17. Conway DV, White RG, Hugues-Dit-Ciles J, Gallienne CP, Robins DB (2003) Guide to the coastal and surface zooplankton of the south western Indian Ocean. Occasional Publication of the Marine Biological Association of the United Kingdom, Plymouth, $354 \mathrm{pp}$

18. Cornils A, Niehoff B, Richter C, Al-Najjar T, Schnack-Schiel SB (2007) Seasonal abundance and reproduction of Clausocalanid copepods in the northern Gulf of Aqaba (Red Sea). J Plankton Res 29(1):57-70

19. Danda A, Anurag A, Sriskanthan G, Ghosh A, Bandyopadhyay J, Hazra S (2011) Indian Sundarbans Delta: A Vision. World Wide Fund for Nature-India, New Delhi

20. DeLorenzo ME, Scott GI, Ross PE (2001) Toxicity of pesticides to aquatic microorganisms: a review. Environ Toxicol Chem 20:84-98

21. Dur G, Hwang JS, Souissi S, Tseng LC, Wu CH, Hsiao SH, Chen QC (2007) An overview of the influence of hydrodynamics on the spatial and temporal patterns of calanoid copepod communities around Taiwan. J Plankton Res 29(1):i97 -i i116

22. Du P, Jiang ZB, Zhu YL, Tang YB, Liao YB, Chen QZ, Zeng JN, Shou L (2020) What Factors Control the Variations in Abundance, Biomass, and Size of Mesozooplankton in a Subtropical Eutrophic Bay? Estuaries Coast 1 - 13

23. Dube A, Jayaraman G, Rani R (2010) Modelling the effects of variables salinity on the temporal distribution of plankton in shallow coastal lagoons. J Hydro-Environ Res 4(3):199 - 200 
24. Fulton RF (1984) Predation, production and organization of an estuarine copepod community. J Plankton Res 66(3):39941

25. Gallienne CP, Robins DB (2001) Is Oithona the most important copepod in the world's oceans? J Plankton Res 23(12):1421-1432

26. Gao Q, Xu Z, Zhuang P (2008) The relation between distribution of zooplankton and salinity in the Changjiang Estuary. Chin J Oceanol Limn $26(2): 178$ $-1850$

27. Godhantaraman N (2001) Seasonal variations in taxonomic compositions, abundance and food web relationship of microzooplankton in estuarine and mangrove waters, Parangipettai region, South east coast of India. Indian J Mar Sci 30:150-160

28. Gordina AD, Pavlova EV, Ovsyany El, Wilson JG, Kemp RB, Romanov AS (2001) Long-term changes in Sevastopol Bay (the Black Sea) with particular reference to the ichthyoplankton and zooplankton. Estuar Coast Shelf Sci 52(1):1-13

29. Govindasamy C, Kannan L (1991) Rotifers of the Pichavaram mangroves (Southeast Coast of India): A hydrobiological approach. Mahasagar 24(1):39-45

30. Hazra S. Ghosh T, Das Gupta R, Sen G (2002) Sea level and associated changes in the Sundarbans. Sci Cult 68(9/12):309-321

31. Islam MD, Ueda H, Tanaka M (2006) Spatial and seasonal variations in copepod communities related to turbidity maximum along the Chikugo estuarine gradient in the upper Ariake Bay, Japan. Estuar Coast Shelf Sci 68:113-126

32. Jyothibabu R, Madhu NV (2007) Zooplankton. National Institute of Oceanography, India, in: Shetye, S.R., Dileep Kumar M., Shankar, D. (Eds.). The Mandovi and Zuari estuaries. 83 - 90

33. Kasturirangan LR (1963) A key for the identification of the more common planktonic copepod of the Indian coastal waters. Council of Scientific \& Industrial Research, New Delhi

34. Kimmerer WJ (1991) Predatory influences on copepod distributions in coastal waters. Bulletin of Plankton Society of Japan 161-174

35. Kumar R (2003) Effects of Mesocyclops thermocyclopoides (Copepoda: Cyclopoida) predation on the population growth patterns of different prey species. J Freshw Ecol 18(3):383-393

36. Lawal-Are AO. Onyema IC, Akande TR (2010) The water chemistry, crustacean zooplankton and some associated faunal species of a tropical tidal creek in Lagos, Nigeria. Journal of American Science 6(1):81-90

37. Lerberg SB, Holland AF, Sanger DM (2000) Responses of tidal creek macrobenthic communities to the effects of watershed development. Estuaries 23:838-853

38. Madhu NV, Jyothibabu R, Balachandran KK, Honey UK, Martin GD, Vijay JG, Shiyas CA, Gupta VGM, Achuthankutty CT (2007) Monsoonal impact on planktonic standing stock and abundance in a tropical estuary (Cochin backwaters-India). Estuar Coast Shelf Sci 73(1-2):54-64.

https://doi.org/10.1016/j.ecss.2006.12.009

39. Mallin MA, Lewitus AJ (2004) The importance of tidal creek ecosystems. J Exp Mar Biol Ecol 2(298):145-149

40. Magurran AE (1988) Ecological Diversity and its measurement. Princeton University press, Princceton

41. Margalef DR (1958) Information theory in ecology. General System 3:36-71

42. McKinnon AD, Klumpp DW (1997) Mangrove zooplankton of north Queensland, Australia. Hydrobiologia 362(1 - 3): 145 - 160

43. Mishra S, Panigrahy RC (1996) Copepods of Bahuda estuary (Orissa), east coast of India. Indian J Mar Sci 25:98-102

44. Morgan SG (1995) The timing of larval release. In: McEdward L (ed) Ecology of marine invertebrate larvae. Florida. CRC Press, Boca Raton, pp 157-191

45. Mwaluma J, Osore M, Kamau J, Wawiye P (2003) Composition, abundance and seasonality of zooplankton in Mida Creek, Kenya. WIOJMS 2(2):147155

46. Nandy T, Mandal S, Chatterjee M (2018) Intra-monsoonal variation of zooplankton population in the Sundarbans Estuarine System, India. Environ Monit Assess 190 (10). https://doi.org/10. 1007/s10661-018-6969- 8

47. Nandy T, Mandal S (2020) Unravelling the spatio-temporal variation of zooplankton community from the river Matla in the Sundarbans Estuarine System, India. Oceanologia https://doi.org/10.1016/j.oceano2020.03.005

48. Neumann-Leitão S, Paranaguá MN, Valentin JL (1992) The planktonic rotifers of the estuarine lagunar complex of Suape (Pernambuco, Brazil). Hydrobiologia 232(2):133-143

49. Padmavati G, Goswami SC (1996) Zooplankton ecology in the Mandovi - Zuari estuarine system of Goa, West coast of India. Indian J Mar Sci 25:268273

50. Park GS, Marshall HG (2000) The trophic contributions of rotifers in tidal freshwater and estuarine habitats. Estuar Coast Shelf Sci 51:729-742

51. Paul S, Karan S, Ghosh S, Bhattacharya BD (2019) Hourly variation of environment and copepod community of the Ganges River Estuary of India: Perspectives on sampling estuarine zooplankton. Estuar Coast Shelf Sci 230:106441

52. Paturej E, Gutkowska A, Koszałka J, Bowszys M (2017) Effect of physicochemical parameters on zooplankton in the brackish, coastal Vistula Lagoon. Oceanologia 59(1):49-56

53. Pielou EC (1977) Mathematical ecology. John Wiley \& Sons, New York, p 385

54. Posey MH, Alphin TD, Cahoon LB, Lindquist DG, Mallin MA, Nevers MB (2002) Top-down versus bottom-up limitation in benthic infaunal communities: direct and indirect effects. Estuaries 25:999-1014

55. Rakhesh M, Raman AV, Kalavati C, Subramanian BR, Sharma VS, Sunitha Babu E, Sateesh N (2008) Zooplankton community structure across an eddygenerated upwelling band close to a tropical bay-mangrove ecosystem. Mar Biol 154(6):953-972 
56. Rakhesh M, Raman AV, Ganesh T, Chandramohan P, Dehairs F (2013) Small copepods structuring mesozooplankton community dynamics in a tropical estuary-coastal system. Estuar Coast Shelf Sci 126:7-22

57. Rakshit D, Sarkar SK, Bhattacharya BD, Jonathan MP, Biswas JK, Mondal P, Mitra S (2015) Human-induced ecological changes in western part of Indian Sundarban megadelta: a threat to ecosystem stability. Mar Pollut Bull 99 (1 - 2): 186 - 194

58. Ramaiah N, Chatterji A, Madhupratap M (1996) A study on the zooplankton of the Burhabalanga estuary, Orissa coast. Proc Indian National Sci Acad B 62:1e4

59. Ramaiah N, Nair VR (1997) Distribution and abundance of copepods in the pollution gradient zones of Bombay Harbour-Thana creek-Bassein creek, West coast of India. Indian J Mar Sci 26:20-25

60. Sastry AS, Chandramohan P (1995) Zooplankton of Vasishta Godavari estuary, A Pre-pollution status survey. J Mar Biol Ass India 37(1):249-258

61. Salvador B, Bersano JGF (2017) Zooplankton variability in the subtropical estuarine system of Paranaguá Bay, Brazil, in 2012 and 2013 . Estuar Coast Shelf Sci 199:1-13

62. Santhanam P, Perumal P (2003) Diversity of zooplankton in Parangipettai coastal waters, southeast coast of India. J Mar Biol Ass India 45(2):144-151

63. Santhanam P, Perumal P (2012) Effect of temperature, salinity and algal food concentration on population density, growth and survival of marine copepod Oithona rigida Giesbrecht. Indian J Mar Sci 41(4):369-376

64. Sarkar SK (1983) Distribution of estuarine epipelagic zooplankton in and around Sagar Island, West Bengal, India. Ph. D. Thesis. Calcutta University, West Bengal

65. Sarkar SK, Choudhuri A, Choudhuri DK (1985) Seasonal variations of zooplankton in a tidal creek (Mooriganga) of the Hooghly estuary. Bardwan University Science Journal 2(1):113-121

66. Sarkar SK, Singh BN, Choudhury A (1986) Composition and variations in the abundance of zooplankton in the Hooghly estuary, West Bengal, India. Proceedings: Animal Sciences 95(2):125 - 134

67. Sastry AS, Chandramohan P (1995) Zooplankton of Vasishta Godavari estuary, A Pre-pollution status survey. J Mar Biol Ass India 37(1):249-258

68. Sebastian P, Stibor H, Berger S, Diehl S (2012) Effects of water temperature and mixed layer depth on zooplankton body size. Mar Biol 159(11):24312440

69. Selfinova ZP (2008) Taxonomic composition and Interannual variations in numerical density of meroplankton in the Sea of Azov. Russ. J Mar Biol 34(5):263-269

70. Shannon CE, Weinner W (1949) The mathematical theory of communication. University of Illinois. 125

71. Shiel RJ (1995) A guide to identification of Rotifers, Cladocerons and Copepods from Australian inland waters. Co-operative Research Centre for Fresh water Ecology (Identification Guide No. 3).144 pp

72. Simpson EH (1949) Measurement of diversity. Nature 163:688

73. Sotton B, Guillard J, Anneville O, Marechal M, Savichtcheva O, Domaizon I (2014) Trophic transfer of microcystins through the lake pelagic food web: evidence for the role of zooplankton as a vector in fish contamination. Sci Total Environ 466:152-163

74. Sousa W, Attayde JL, Rocha EDS, Eskinazi-Sant'Anna EM (2008) The response of zooplankton assemblages to variations in the water quality of four man-made lakes in semi-arid northeastern Brazil. J Plankton Res 30(6):699-708

75. Srichandan S, Sahu BK, Panda R. Baliarsingh SK, Sahu KC, Panigrahy RC (2015) Zooplankton distribution in coastal water of the North-Western Bay of Bengal, off Rushikulya estuary, East coast of India. Indian J Mar Sci 44(4):546-561

76. Strickland JDH, Parsons TR (1972) A practical handbook of sea - water analysis. Fish Res Canada, Ottawa, 328 pp

77. Sun J, Liu DY, Bai J, Gao HW, Han XT (2004) Phytoplankton community of the Bohai Sea in Winter 2001. J Ocean Univ China 34(3):403-422

78. Thabet R, Leignel V, Ayadi H, Tastard E (2018) Interannual and seasonal effects of environmental factors on the zooplankton distribution in the solar saltern of Sfax (South-Western Mediterranean Sea). Cont Shelf Res 165:1-11

79. Tommasi D, Hunt BPV, Pakhomov EA, Mackas DL (2013) Mesozooplankton community seasonal succession and its drivers: Insights from a British Columbia, Canada, fjord. J Mar Syst115 - 116:10 - 32

80. Turner JT, Dagg MJ (1983) Vertical distributions of continental shelf zooplankton in stratified and isothermal waters. Biological Oceanography 3(1):140

81. Turner JT (2004) The importance of small planktonic copepods and their roles in pelagic marine food webs. Zool Stud 432:255-266

82. Uye S, Shimazu T, Yamamuro M, Ishitobi Y, Kamiya H (2000) Geographical and seasonal variations in mesozooplankton abundance and biomass in relation to environmental parameters in Lake Shinji-Ohashi River-Lake Nakaumi brackish-water system, Japan. J Mar Syst 26(2):193-207

83. Varghese M, Krishnan L (2009) Distribution of zooplankton in selected centres of Cochin backwaters, Kerala. J Mar Biol Ass India 51(2):194-198

84. Vernberg FJ, Vernberg WB (2001) The Coastal Zone. University of South Carolina Press, Columbia, 191 pp

85. Warwick RM, Clarke R (1993) Increased variability as symptom of stress in marine communities. J Exp Mar Biol Ecol 172:215-226

86. Wiegert RG, Freeman BJ (1990) Tidal salt marshes of the southeast Atlantic Coast: a community profile. US Fish Wildlife Service Biological Reports 85(29):67

\section{Tables}

Table 1 Variations of physico-chemical parameters of studied locations of Sagar island, Sundarbans

Page $11 / 19$ 


\begin{tabular}{|c|c|c|c|c|c|c|c|c|c|c|c|c|}
\hline Stations & Seasons & $\mathrm{pH}$ & Temp. $\left({ }^{\circ} \mathrm{C}\right)$ & $\begin{array}{c}\text { Salinity } \\
\text { (ppt) }\end{array}$ & $\begin{array}{c}\mathrm{DO} \\
\left(\mathrm{mgl}^{-1}\right)\end{array}$ & $\begin{array}{c}\text { Turbidity } \\
\text { (NTU) }\end{array}$ & $\begin{array}{c}\text { COD } \\
\left(\mathrm{mgl}^{-1}\right)\end{array}$ & $\begin{array}{c}\text { BOD } \\
\left(\mathrm{mgl}^{-1}\right)\end{array}$ & $\begin{array}{l}\mathrm{PO}_{4}-\mathrm{P} \\
\left(\mathrm{mgl}^{-1}\right)\end{array}$ & $\begin{array}{c}\mathrm{NO}_{3}-\mathrm{N} \\
\left(\mathrm{mgl}^{-1}\right)\end{array}$ & $\begin{array}{c}\mathrm{SiO}_{4}-\mathrm{Si} \\
\left(\mathrm{mgl}^{-1}\right)\end{array}$ & $\begin{array}{c}\mathrm{NO}_{2}-\mathrm{N} \\
\left(\mathrm{mgl}^{-1}\right)\end{array}$ \\
\hline SIK & MON & $7.26 \pm 0.24$ & $27.55 \pm 0.65$ & $6.91 \pm 7.91$ & $6.44 \pm 0.97$ & $74.38 \pm 9.33$ & $83.75 \pm 37.65$ & $2.41 \pm 1.31$ & $6.11 \pm 2.55$ & $8.57 \pm 5.57$ & $4.47 \pm 2.01$ & $0.52 \pm 0.28$ \\
\hline \multirow[t]{2}{*}{ (S1) } & POM & $7.165 \pm 0.23$ & $20.15 \pm 3.53$ & $13.45 \pm 3.45$ & $7.26 \pm 0.47$ & $26.79 \pm 19.34$ & $70.25 \pm 58.86$ & $6.02 \pm 3.92$ & $3.40 \pm 1.97$ & $2.58 \pm 1.11$ & $3.16 \pm 0.41$ & $0.36 \pm 0.21$ \\
\hline & PRM & $7.17 \pm 0.38$ & $31.00 \pm 2.41$ & $17.89 \pm 4.60$ & $5.80 \pm 0.63$ & $64.01 \pm 26.37$ & $86.63 \pm 46.47$ & $3.12 \pm 1.47$ & $13.17 \pm 4.04$ & $5.35 \pm 3.17$ & $10.32 \pm 5.54$ & $0.90 \pm 0.63$ \\
\hline \multirow{3}{*}{$\begin{array}{l}\text { SAG } \\
(\mathrm{S} 2)\end{array}$} & $\mathrm{MON}$ & $7.43 \pm 0.20$ & $27.66 \pm 0.97$ & $6.53 \pm 6.44$ & $6.40 \pm 0.59$ & $61.54 \pm 13.03$ & $77.38 \pm 15.45$ & $2.38 \pm 1.07$ & $3.13 \pm 2.58$ & $10.28 \pm 6.45$ & $3.29 \pm 1.21$ & $0.54 \pm 0.38$ \\
\hline & POM & $7.43 \pm 0.33$ & $20.89 \pm 3.19$ & $17.14 \pm 6.42$ & $7.20 \pm 0.40$ & $37.05 \pm 36.40$ & $52.38 \pm 41.03$ & $3.80 \pm 0.85$ & $1.71 \pm 0.65$ & $3.51 \pm 2.65$ & $6.55 \pm 5.28$ & $0.34 \pm 0.29$ \\
\hline & PRM & $7.23 \pm 0.46$ & $29.70 \pm 2.18$ & $22.91 \pm 4.39$ & $5.81 \pm 0.92$ & $55.08 \pm 30.13$ & $84.38 \pm 41.87$ & $2.99 \pm 1.96$ & $6.90 \pm 3.48$ & $3.26 \pm 1.26$ & $11.34 \pm 6.84$ & $1.02 \pm 0.72$ \\
\hline \multirow{3}{*}{$\begin{array}{l}\text { HAT } \\
\text { (S3) }\end{array}$} & MON & $7.44 \pm 0.25$ & $28.03 \pm 0.60$ & $7.74 \pm 7.75$ & $6.08 \pm 0.83$ & $77.70 \pm 8.37$ & $76.88 \pm 17.86$ & $2.11 \pm 0.96$ & $6.58 \pm 2.33$ & $8.95 \pm 4.18$ & $4.70 \pm 2.45$ & $0.85 \pm 0.53$ \\
\hline & POM & $7.47 \pm 0.46$ & $20.99 \pm 3.38$ & $13.80 \pm 2.76$ & $7.58 \pm 0.27$ & $23.35 \pm 14.48$ & $61.25 \pm 38.34$ & $2.24 \pm 1.59$ & $2.78 \pm 2.03$ & $5.77 \pm 2.80$ & $6.19 \pm 3.33$ & $0.31 \pm 0.24$ \\
\hline & PRM & $7.17 \pm 0.43$ & $30.70 \pm 2.23$ & $19.81 \pm 4.90$ & $5.79 \pm 0.91$ & $58.50 \pm 18.61$ & $89.50 \pm 53.51$ & $3.89 \pm 2.06$ & $10.28 \pm 4.50$ & $7.33 \pm 2.74$ & $7.97 \pm 4.65$ & $0.60 \pm 0.39$ \\
\hline \multirow{3}{*}{$\begin{array}{l}\text { CHE } \\
\text { (S4) }\end{array}$} & $\mathrm{MON}$ & $7.50 \pm 0.10$ & $28.15 \pm 0.95$ & $6.57 \pm 7.10$ & $6.48 \pm 0.49$ & $64.38 \pm 8.34$ & $82.75 \pm 30.77$ & $1.31 \pm 0.99$ & $5.94 \pm 3.10$ & $7.64 \pm 4.62$ & $4.71 \pm 0.62$ & $1.09 \pm 0.86$ \\
\hline & POM & $7.33 \pm 0.52$ & $20.7 \pm 3.12$ & $12.99 \pm 4.19$ & $7.10 \pm 0.87$ & $23.78 \pm 19.38$ & $62.50 \pm 49.68$ & $1.73 \pm 0.88$ & $2.34 \pm 1.48$ & $2.57 \pm 1.39$ & $5.83 \pm 3.57$ & $0.31 \pm 0.25$ \\
\hline & PRM & $7.44 \pm 0.45$ & $30.90 \pm 2.22$ & $20.14 \pm 1.55$ & $5.51 \pm 0.33$ & $64.88 \pm 31$ & $61.88 \pm 30.77$ & $3.54 \pm 2.07$ & $10.18 \pm 4.64$ & $8.44 \pm 6.04$ & $8.61 \pm 2.69$ & $0.79 \pm 0.55$ \\
\hline \multirow{3}{*}{$\begin{array}{l}\text { PHO } \\
\text { (S5) }\end{array}$} & MON & $7.33 \pm 0.19$ & $28.35 \pm 0.82$ & $3.82 \pm 4.34$ & $6.46 \pm 0.52$ & $67.63 \pm 6.81$ & $90.88 \pm 14.34$ & $3.66 \pm 2.6$ & $6.21 \pm 2.87$ & $8.70 \pm 3.16$ & $4.95 \pm 2.14$ & $0.79 \pm 0.60$ \\
\hline & POM & $7.44 \pm 0.29$ & $20.13 \pm 3.21$ & $10.05 \pm 1.36$ & $7.32 \pm 0.64$ & $23.20 \pm 16.31$ & $64.75 \pm 46.39$ & $2.20 \pm 1.41$ & $4.85 \pm 1.87$ & $4.33 \pm 1.56$ & $9.60 \pm 4.84$ & $0.53 \pm 0.31$ \\
\hline & PRM & $7.44 \pm 0.26$ & $29.35 \pm 2.12$ & $16.86 \pm 2.64$ & $6.14 \pm 0.81$ & $39.39 \pm 13.82$ & $70.00 \pm 47.48$ & $2.90 \pm 1.57$ & $5.77 \pm 1.50$ & $5.29 \pm 3.02$ & $5.93 \pm 1.12$ & $0.67 \pm 0.58$ \\
\hline \multirow{3}{*}{$\begin{array}{l}\text { KAC } \\
\text { (S6) }\end{array}$} & MON & $7.51 \pm 0.31$ & $27.80 \pm 0.82$ & $5.21 \pm 5.71$ & $6.29 \pm 0.57$ & $88.63 \pm 16.25$ & $90.00 \pm 12.88$ & $2.82 \pm 1.04$ & $4.72 \pm 2.83$ & $10.37 \pm 6.35$ & $3.66 \pm 2.60$ & $0.81 \pm 0.48$ \\
\hline & POM & $7.53 \pm 0.33$ & $20.06 \pm 3.48$ & $10.34 \pm 1.04$ & $6.75 \pm 0.26$ & $31.10 \pm 15.71$ & $67.75 \pm 53.37$ & $2.23 \pm 1.35$ & $3.41 \pm 0.54$ & $3.57 \pm 2.10$ & $9.76 \pm 5.35$ & $0.59 \pm 0.27$ \\
\hline & PRM & $7.43 \pm 0.26$ & $30.29 \pm 2.47$ & $16.68 \pm 3.44$ & $5.76 \pm 0.70$ & $62.90 \pm 27.11$ & $49.00 \pm 31.14$ & $2.97 \pm 2.45$ & $8.19 \pm 2.33$ & $6.89 \pm 4.01$ & $11.32 \pm 6.33$ & $1.02 \pm 0.68$ \\
\hline
\end{tabular}

( $\mathrm{MON}=$ monsoon; POM=Post-monsoon; PRM=Pre-monsoon and the ' \pm values' denotes the standard deviation; $\mathrm{n}=8$ )

Table 2 Intra-relationship of water quality parameters and major groups of zooplankton

\begin{tabular}{|c|c|c|c|c|c|c|c|c|c|c|c|c|c|c|c|c|c|c|c|}
\hline 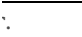 & $\mathrm{pH}$ & Temp. & Sal & $\mathrm{DO}$ & Tur & BOD & $\mathrm{PO}_{4}-\mathrm{P}$ & $\mathrm{NO}_{3}-\mathrm{N}$ & $\mathrm{NO}_{2}-\mathrm{N}$ & $\mathrm{SiO}_{4}-\mathrm{Si}$ & COPE & CLAD & ROTI & CHAE & NAUP & LARV & EGGS & MYSI & TZP \\
\hline & 1 & & & & & & & & & & & & & & & & & & \\
\hline . & 0.039 & 1 & & & & & & & & & & & & & & & & & \\
\hline \multirow[t]{2}{*}{ nity } & -0.214 & 0.44 & 1 & & & & & & & & & & & & & & & & \\
\hline & 0.148 & $-.877^{* *}$ & -0.331 & 1 & & & & & & & & & & & & & & & \\
\hline bidity & 0.156 & $.682^{* *}$ & -0.37 & $-.601 * *$ & 1 & & & & & & & & & & & & & & \\
\hline D & 0.333 & -0.13 & -0.12 & 0.182 & 0.101 & 1 & & & & & & & & & & & & & \\
\hline$-\mathrm{P}$ & -0.13 & $.535 *$ & 0.443 & $-.723^{* *}$ & 0.435 & -0.221 & 1 & & & & & & & & & & & & \\
\hline${ }_{3}-\mathrm{N}$ & 0.432 & $.575^{*}$ & $-.503 *$ & -0.371 & $.771 * *$ & 0.049 & 0.192 & 1 & & & & & & & & & & & \\
\hline $2-\mathrm{N}$ & -0.053 & $0.573^{*}$ & -0.15 & $-0.473^{*}$ & $0.612^{* *}$ & 0.009 & 0.423 & 0.224 & 1 & & & & & & & & & & \\
\hline $4^{-\mathrm{Si}}$ & -0.167 & 0.387 & $.751 * *$ & $-.591 * *$ & 0.127 & -0.108 & $.667 * *$ & -0.251 & 0.218 & 1 & & & & & & & & & \\
\hline ?E & -0.207 & -0.385 & $0.557 *$ & 0.306 & -0.421 & 0.447 & -0.165 & $-.479 *$ & 0.052 & 0.152 & 1 & & & & & & & & \\
\hline $\mathrm{tD}$ & 0.178 & -0.143 & 0.367 & -0.086 & $-0.60 * *$ & -0.005 & 0.031 & -0.128 & $0.548 *$ & 0.224 & 0.235 & 1 & & & & & & & \\
\hline ГІ & 0.323 & -0.089 & -0.332 & 0.138 & 0.201 & -0.011 & -0.307 & 0.216 & 0.26 & -0.307 & 0.103 & 0.466 & 1 & & & & & & \\
\hline$A E$ & 0.035 & $-0.542 *$ & 0.048 & 0.246 & -0.312 & 0.320 & -0.315 & -0.299 & -0.07 & -0.136 & 0.102 & $.558 *$ & 0.467 & 1 & & & & & \\
\hline UP & -0.379 & 0.227 & $.657 * *$ & -0.429 & -0.101 & 0.329 & $.549 *$ & -0.262 & 0.007 & $.552 *$ & 0.259 & -0.17 & -0.344 & -0.113 & 1 & & & & \\
\hline रV & -0.195 & -0.186 & $.652 * *$ & -0.033 & -0.318 & 0.419 & 0.254 & $-.612^{* *}$ & 0.062 & $.614^{* *}$ & $.549 *$ & 0.136 & -0.195 & 0.037 & $.541 *$ & 1 & & & \\
\hline 3S & -0.307 & $-.570 *$ & 0.159 & 0.448 & $-.508 *$ & $0.579^{*}$ & $-.478 *$ & $-.627^{* *}$ & -0.14 & -0.043 & $.580 *$ & 0.151 & 0.069 & 0.39 & 0.091 & $.556^{*}$ & 1 & & \\
\hline SI & -0.083 & -0.179 & 0.075 & 0.135 & -0.154 & 0.025 & -0.044 & -0.085 & 0.117 & -0.07 & 0.127 & 0.109 & -0.31 & 0.117 & 0.064 & -0.214 & 0.177 & 1 & \\
\hline , & -0.288 & -0.336 & $.617 * *$ & 0.173 & -0.43 & $0.508^{*}$ & 0.006 & $-.575 *$ & 0.093 & 0.342 & $.959 * *$ & 0.247 & 0.002 & 0.136 & $.473^{*}$ & $.705^{* *}$ & $.613^{* *}$ & 0.155 & 1 \\
\hline
\end{tabular}

**. Correlation is significant at the 0.01 level (2-tailed).

*. Correlation is significant at the 0.05 level (2-tailed).

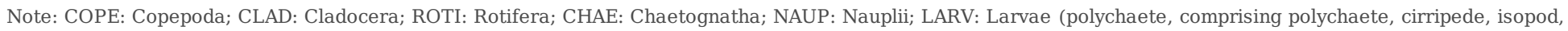
amphipod, gastropod and fish larvae); Eggs: Resting eggs (copepods, rotifers, fish); MYSI: Mysids; TZP: Total zooplankton

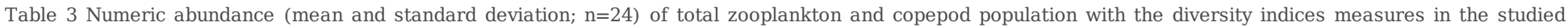
stations

\begin{tabular}{|c|c|c|c|c|c|c|c|}
\hline Stations & $\begin{array}{l}\text { Total zooplankton } \\
\text { abundance (ind.m }{ }^{-3} \text { ) }\end{array}$ & Total Copepod abundance (ind. $\mathrm{m}^{-3}$ ) & Copepod contribution (\%) & $\begin{array}{l}\text { Richness } \\
(d \square)\end{array}$ & $\begin{array}{l}\text { Shannon } \\
\text { Diversity }(H \square)\end{array}$ & $\begin{array}{l}\text { Simpson diversity } \\
(1-\lambda \square)\end{array}$ & Evenness $(J \square)$ \\
\hline S1 & $42.33 \pm 27.43$ & $26.63 \pm 20.41$ & 69.92 & $4.48 \pm 1.53$ & $2.43 \pm 0.65$ & $0.88 \pm 0.17$ & $0.78 \pm 0.19$ \\
\hline $\mathrm{S} 2$ & $41.86 \pm 25.01$ & $27.58 \pm 15.56$ & 65.89 & $3.93 \pm 1.29$ & $2.27 \pm 0.55$ & $0.86 \pm 0.15$ & $0.75 \pm 0.16$ \\
\hline S3 & $43.66 \pm 16.16$ & $29.72 \pm 10.71$ & 68.06 & $4.47 \pm 1.23$ & $2.48 \pm 0.53$ & $0.89 \pm 0.15$ & $0.78 \pm 0.16$ \\
\hline S4 & $28.50 \pm 14.42$ & $16.97 \pm 7.70$ & 59.55 & $3.46 \pm 1.22$ & $2.04 \pm 0.62$ & $0.82 \pm 0.18$ & $0.76 \pm 0.18$ \\
\hline S5 & $45.55 \pm 20.68$ & $29.33 \pm 17.32$ & 73.13 & $4.09 \pm 0.81$ & $2.29 \pm 0.47$ & $0.85 \pm 0.16$ & $0.73 \pm 0.22$ \\
\hline S6 & $40.88 \pm 14.64$ & $27.11 \pm 16.34$ & 66.30 & $4.39 \pm 0.94$ & $2.44 \pm 0.51$ & $0.88 \pm 0.16$ & $0.77 \pm 0.19$ \\
\hline
\end{tabular}

The abundance of total zooplankton and total copepods are expressed in thousands 
Table 4 Correlation matrix showing the intra-relationship of copepod families

\begin{tabular}{|c|c|c|c|c|c|c|c|c|c|c|c|c|c|c|c|c|c|}
\hline Family & PARA & ACAR & EUCAL & PSEU & TEMO & CAND & CALA & CENT & PONT & TORT & OITH & ONCE & CYCL & MIRA & ECTI & LONG & CLYT \\
\hline PARA & 1 & & & & & & & & & & & & & & & & \\
\hline ACAR & -0.064 & 1 & & & & & & & & & & & & & & & \\
\hline EUCAL & 0.09 & -0.15 & 1 & & & & & & & & & & & & & & \\
\hline PSEU & 0.189 & 0.426 & -0.385 & 1 & & & & & & & & & & & & & \\
\hline TEMO & 0.262 & -0.192 & $.728 * *$ & -0.172 & 1 & & & & & & & & & & & & \\
\hline CAND & $.554^{*}$ & 0.042 & -0.158 & 0.356 & 0.070 & 1 & & & & & & & & & & & \\
\hline CALA & -0.131 & $.614^{* *}$ & -0.219 & $.546 *$ & 0.050 & -0.168 & 1 & & & & & & & & & & \\
\hline CENT & 0.037 & $.578^{*}$ & -0.406 & 0.315 & -0.294 & -0.032 & $.567 *$ & 1 & & & & & & & & & \\
\hline PONT & 0.130 & 0.227 & 0.086 & 0.369 & 0.331 & -0.168 & 0.457 & 0.189 & 1 & & & & & & & & \\
\hline TORT & 0.105 & -0.223 & 0.461 & -0.097 & $.655^{* *}$ & -0.173 & 0.202 & -0.193 & 0.151 & 1 & & & & & & & \\
\hline OITH & $.489 *$ & $.670^{* * *}$ & -0.023 & $.609 * *$ & 0.130 & 0.396 & $.508^{*}$ & 0.357 & 0.438 & 0.1 & 1 & & & & & & \\
\hline ONCE & $.752 * *$ & 0.011 & 0.175 & 0.046 & 0.182 & $.472 *$ & -0.186 & -0.112 & -0.123 & -0.087 & 0.232 & 1 & & & & & \\
\hline CYCL & 0.132 & 0.066 & -0.092 & 0.189 & -0.195 & -0.28 & 0.218 & 0.362 & 0.121 & -0.201 & -0.102 & 0.232 & 1 & & & & \\
\hline MIRA & 0.243 & 0.218 & 0.324 & 0.184 & 0.201 & 0.312 & -0.019 & 0.204 & 0.158 & -0.129 & 0.160 & 0.334 & $.473^{*}$ & 1 & & & \\
\hline ECTI & $.594 * *$ & 0.123 & 0.137 & 0.434 & 0.066 & $.566^{*}$ & 0.071 & 0.161 & -0.012 & -0.096 & 0.357 & $.663^{* *}$ & 0.444 & $.625^{* * *}$ & 1 & & \\
\hline LONG & $.520 *$ & 0.153 & -0.052 & 0.353 & 0.072 & $.483^{*}$ & 0.131 & -0.046 & 0.027 & -0.110 & 0.338 & $.789 * *$ & 0.062 & 0.125 & $.637^{* *}$ & 1 & \\
\hline CLYT & 0.128 & $.484 *$ & 0.327 & $.504 *$ & 0.129 & 0.180 & 0.207 & 0.042 & 0.088 & 0.230 & 0.435 & 0.081 & 0.048 & 0.435 & 0.377 & 0.106 & 1 \\
\hline
\end{tabular}

*. Correlation is significant at the 0.05 level (2-tailed).

**. Correlation is significant at the 0.01 level (2-tailed).

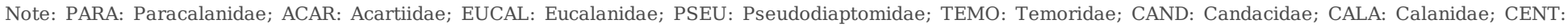

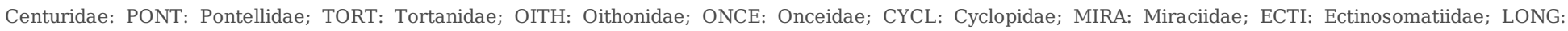
Longipadidae; CLYT: Clytemnesteridae

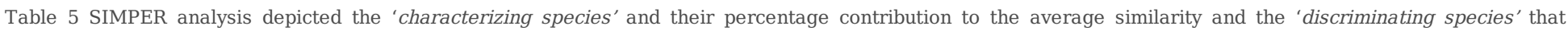
contribute to the maximum dissimilarity between the assemblages (stations) 


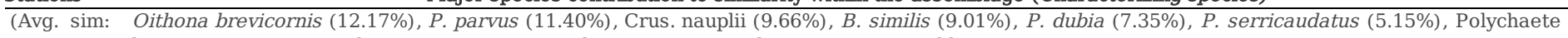
69\%) larvae (4.34\%), O. similis (4.18\%), A. spinicauda (4.10\%), A. erythraea (3.8\%), A. gibber (3.66\%)

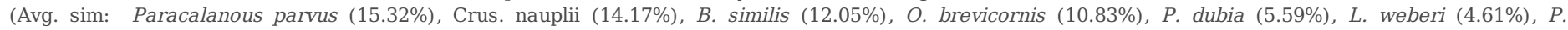

63\%) annadalei (4.12\%), A. spinicauda (4.10), O. venusta (4.02\%), A. gracilis (3.2\%)

(Avg. sim: C. naulii (12.4\%), P. parvus (11.87\%), B. similis (10.92\%), Mysids (9.76\%), O. brevicornis (9.70\%), P. dubia (5.49\%), P. serricaudatus (4.04\%)

97\%)

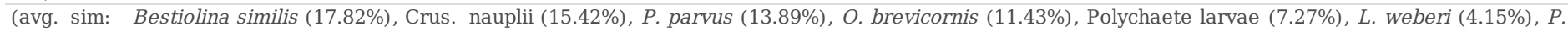
19\%) dubia (4.07\%), P. serricaudatus (3.7\%), P. aurivilli (3.42\%), Microsetella norvegica (3.1\%)

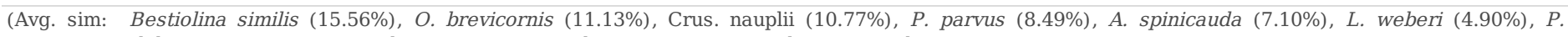
01\%) dubia (4.75\%), P. serricaudatus (4.7\%), A. erythraea (4.1\%), Acrocalanous gracilis (3.7\%)

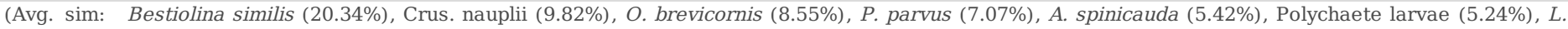
$73 \%)$ weberi (4.57\%), P. dubia (3.34\%), Pseudodiaptomus aurivilli (3.1\%), Microsetella norvegica (2.86\%)

\section{Avg. dissimilarity Discriminating species}

Paracalanous parvus (5.85\%), Crus. nauplii (5.44\%), O. brevicornis (5.29\%), B. similis (4.71\%), A. plumosa (4.41\%), A. gibber (4.11\%)

2 (55.34\%)

$55.34 \%)$

\& Crus. nauplii (6.23\%), Mysids (5.93\%), P. parvus (5.37\%), B. similis (5.12\%), O. brevicornis (4.94\%), P. dubia (4.94\%)

\& $\quad$ S3 Mysids (7.36\%), Crus. nauplii (6.335\%), P. parvus (5.71\%), O. brevicornis (5.13\%), P. dubia (4.50\%) $.58 \%)$

$27 \%)$

$91 \%)$

$\&$

$.93 \%)$

\&

$.25 \%)$

$\&$

$.34 \%)$

$\&$

$.15 \%)$

\&

$.48 \%)$

$\&$

$.81 \%)$

\&

$\&$

$.21 \%)$

\& $.01 \%)$

S4 Crus. nauplii (6.89\%), B. similis (6.34\%), O. brevicornis (5.39\%), Polychaete larvae (4.78\%), P. parvus (4.66\%), Mysids (4.62\%), P. dubia (4.38\%), A. plumosa $(4.33 \%)$

4 Crus. nauplii (7.57\%), P. parvus (6.35\%), O. brevicornis (5.61\%), B. similis (5.32\%), Mysids (4.76\%), Polychaete larvae (4.60\%)

S4 Mysids (8.04\%), Crus. nauplii (8.02\%), P. parvus (5.59\%), O. brevicornis (5.28\%), B. similis (5.19\%), P. dubia (5.17\%)

S5 Bestiolina similis (7.92\%), O. brevicornis (6.08\%), P. parvus (5.73\%), Crus. nauplii (4.80\%), P. dubia (4.18\%)

S5 Bestiolina similis (6.85\%), P. parvus (6.75\%), O. brevicornis (6.32\%), Crus. nauplii (5.50\%)

S5 Bestiolina similis (8.04\%), Crus. nauplii (8.02\%), P. parvus (5.5\%), Mysids (5.2\%), O. brevicornis (5.1\%), P. dubia (5.1\%)

S5 Bestiolina similis (7.98\%), Crus. nauplii (7.18\%), O. brevicornis (6.68\%), P. parvus (5.76\%), Mysids (4.64\%), Polychaete larvae (4.25\%)

S6 Polychaete larvae (5.75\%), O. brevicornis (5.29\%), B. similis (5.19\%), Crus. nauplii (4.86\%), P. parvus (4.79\%)

S6 Paracalanous parvus (6.20\%), Crus. nauplii (5.65\%), Polychaete larvae (5.60\%), O. brevicornis (5.34\%)

S6 Crus. nauplii (6.51\%), Mysids (6.0\%), P. parvus (5.74\%), O. brevicornis (5.23\%), Polychaete larvae (4.85\%), P. dubia (4.58\%)

S6 Crus. nauplii (7.32\%), Polychaete larvae (7.03\%), O. brevicornis (5.14\%), P. parvus (4.92\%), B. similis (4.58\%), Mysids (4.51\%)

S6 Oithona brevicornis (6.37\%), P. parvus (5.65\%), B. similis (5.63\%), Polychaete larvae (5.56\%), Crus. nauplii (5.23\%)

Table 6 BIO-ENV analysis observed in the zooplankton community compared with environmental variables

\begin{tabular}{clc}
\hline No. of variables & Parameters & Spearman correlation \\
\hline 2 & Salinity, $\mathrm{PO}_{4}-\mathrm{P}$ & 0.210 \\
3 & Salinity, $\mathrm{PO}_{4}-\mathrm{P}, \mathrm{NO}_{3}-\mathrm{N}$ & 0.203 \\
\hline 3 & $\mathrm{pH}$, Salinity, $\mathrm{PO}_{4}-\mathrm{P}$ & 0.202 \\
\hline 4 & $\mathrm{pH}$, Salinity, $\mathrm{PO}_{4}-\mathrm{P}, \mathrm{NO}_{3}-\mathrm{N}$ & 0.197 \\
4 & Salinity, $\mathrm{BOD}, \mathrm{PO}_{4}-\mathrm{P}, \mathrm{NO}_{3}-\mathrm{N}$ & 0.184 \\
\hline 2 & Salinity, $\mathrm{NO}_{3}-\mathrm{N}$ & 0.177 \\
\hline 5 & $\mathrm{pH}$, Salinity, $\mathrm{BOD}, \mathrm{PO}_{4}-\mathrm{P}, \mathrm{NO}_{3}-\mathrm{N}$ & 0.174 \\
\hline 3 & Salinity, Turbidity, $\mathrm{PO}_{4}-\mathrm{P}$ & 0.173 \\
\hline 1 & Salinity & 0.170 \\
\hline
\end{tabular}

Table 7 Marginal and sequential tests of environmental variables and the abundance of zooplankton 


\begin{tabular}{|c|c|c|c|}
\hline MARGINAL TESTS & & & \\
\hline Variable & SS & Pseudo-F & $\mathrm{P}$ \\
\hline $\mathrm{pH}$ & 979.65 & 0.90426 & 0.592 \\
\hline Temp. & 2465.1 & 2.3208 & 0.007 \\
\hline Salinity & 3936.3 & 3.7807 & 0.001 \\
\hline $\mathrm{DO}$ & 1864.7 & 1.7415 & 0.033 \\
\hline Turbidity & 1765.6 & 1.6467 & 0.046 \\
\hline BOD & 801.59 & 0.73817 & 0.77 \\
\hline $\mathrm{PO}_{4}-\mathrm{P}$ & 2196.7 & 2.0607 & 0.016 \\
\hline $\mathrm{NO}_{3}-\mathrm{N}$ & 1817.2 & 1.6961 & 0.03 \\
\hline $\mathrm{SiO}_{4}-\mathrm{Si}$ & 2486 & 2.3412 & 0.053 \\
\hline \multicolumn{4}{|l|}{ SEQUENTIAL TESTS } \\
\hline Variable & SS & Pseudo-F & $\mathrm{P}$ \\
\hline Temp. & 3936.3 & 3.7807 & 0.001 \\
\hline Salinity & 2757.8 & 2.7137 & 0.001 \\
\hline
\end{tabular}

Table 8 Distance-based linear model (DistLM) that fitted for the relationship between zooplankton abundance and environmental variables

\begin{tabular}{llcccc}
\hline \multicolumn{2}{l}{ Axis } & $\begin{array}{c}\text { \% Explained variation out of fitted model } \\
\text { Individual }\end{array}$ & $\begin{array}{c}\text { \% Explained variation out of total variation } \\
\text { Cumulative }\end{array}$ & $\begin{array}{c}\text { Individual } \\
\text { Cumulative }\end{array}$ \\
\hline 1 & Salinity & 69.75 & 69.75 & 6.08 & 6.08 \\
2 & Temp. & 30.25 & 100 & 2.64 & 8.71 \\
\hline
\end{tabular}

\section{Figures}

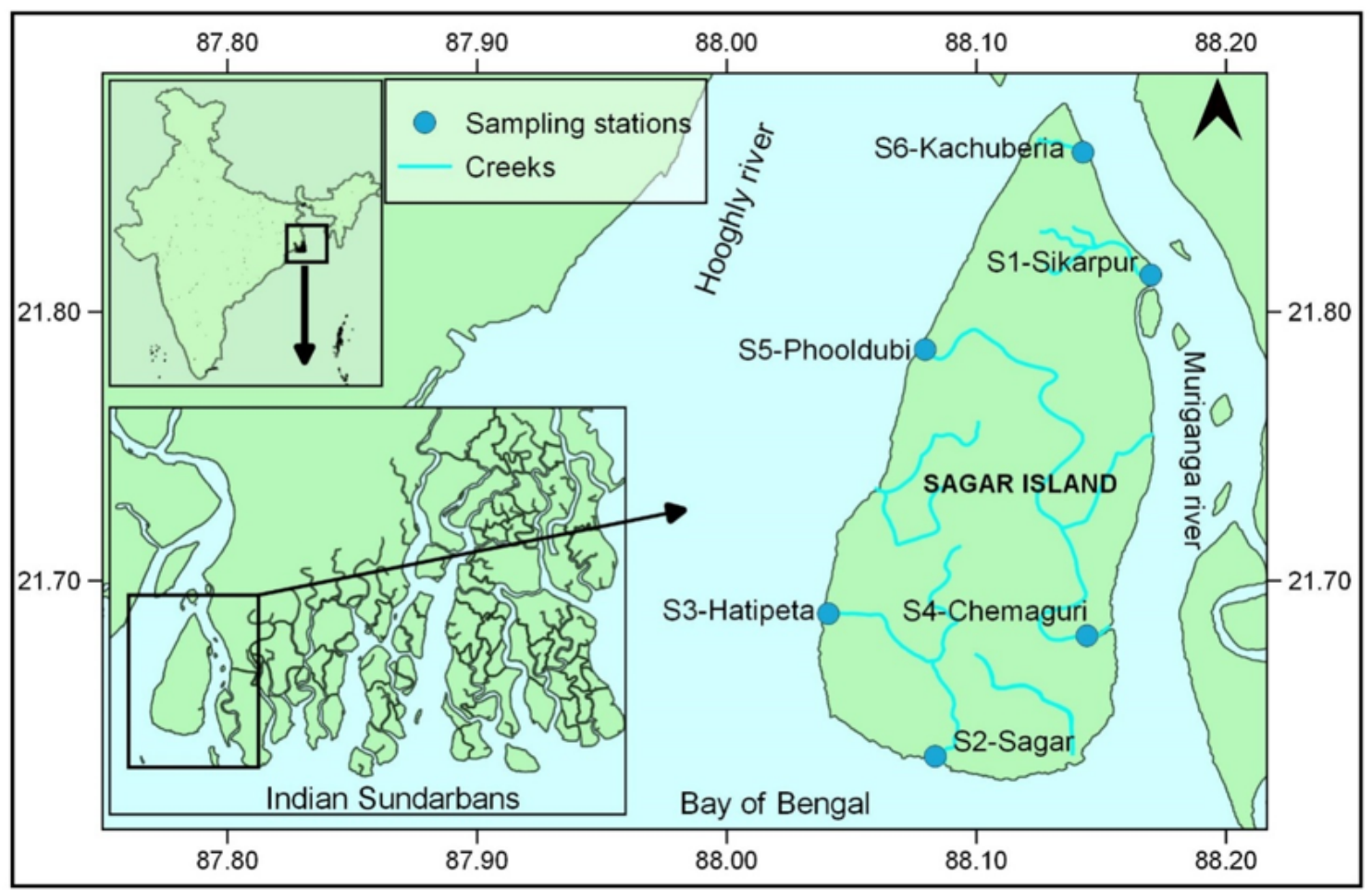

Figure 1

The geographical locations of the sampling sites and study area of Sagar Island, Sundarbans Note: The designations employed and the presentation of the material on this map do not imply the expression of any opinion whatsoever on the part of Research Square concerning the legal status of any country, territory, city or area or of its authorities, or concerning the delimitation of its frontiers or boundaries. This map has been provided by the authors. 


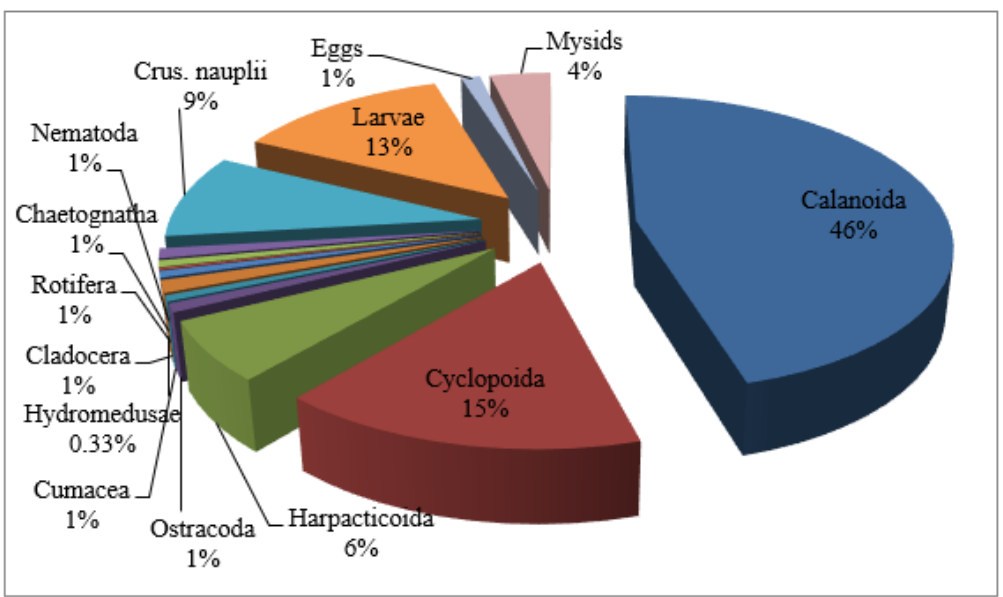

Figure 2

Percentage composition of zooplankton in the studied stations

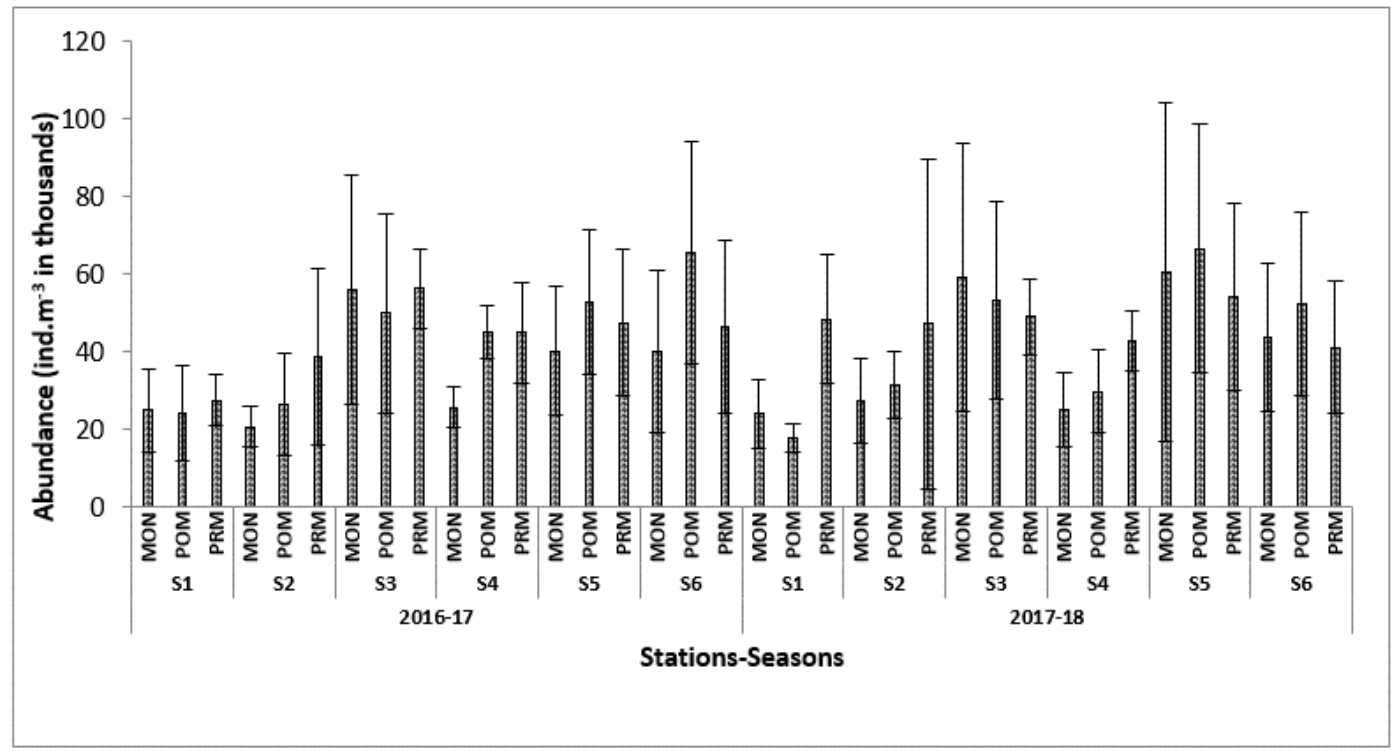

Figure 3

Mean abundance of total zooplankton in studied stations with seasons 

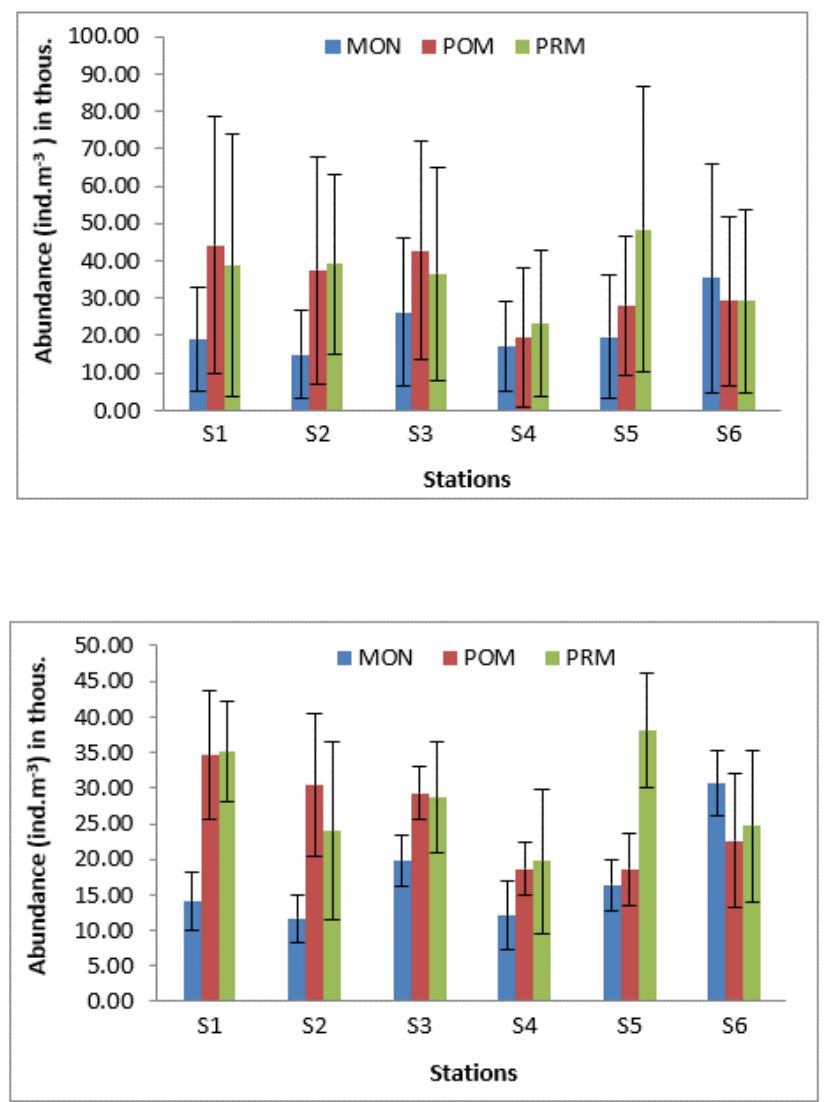

\section{Figure 4}

Top panel: a \& Bottom panel:b Spatio-temporal variations in abundance of (a) Holoplankters (top panel) and (b) Meroplankters (bottom panel); MON: Monsoon; POM: Post-monsoon; PRM: Pre-monsoon

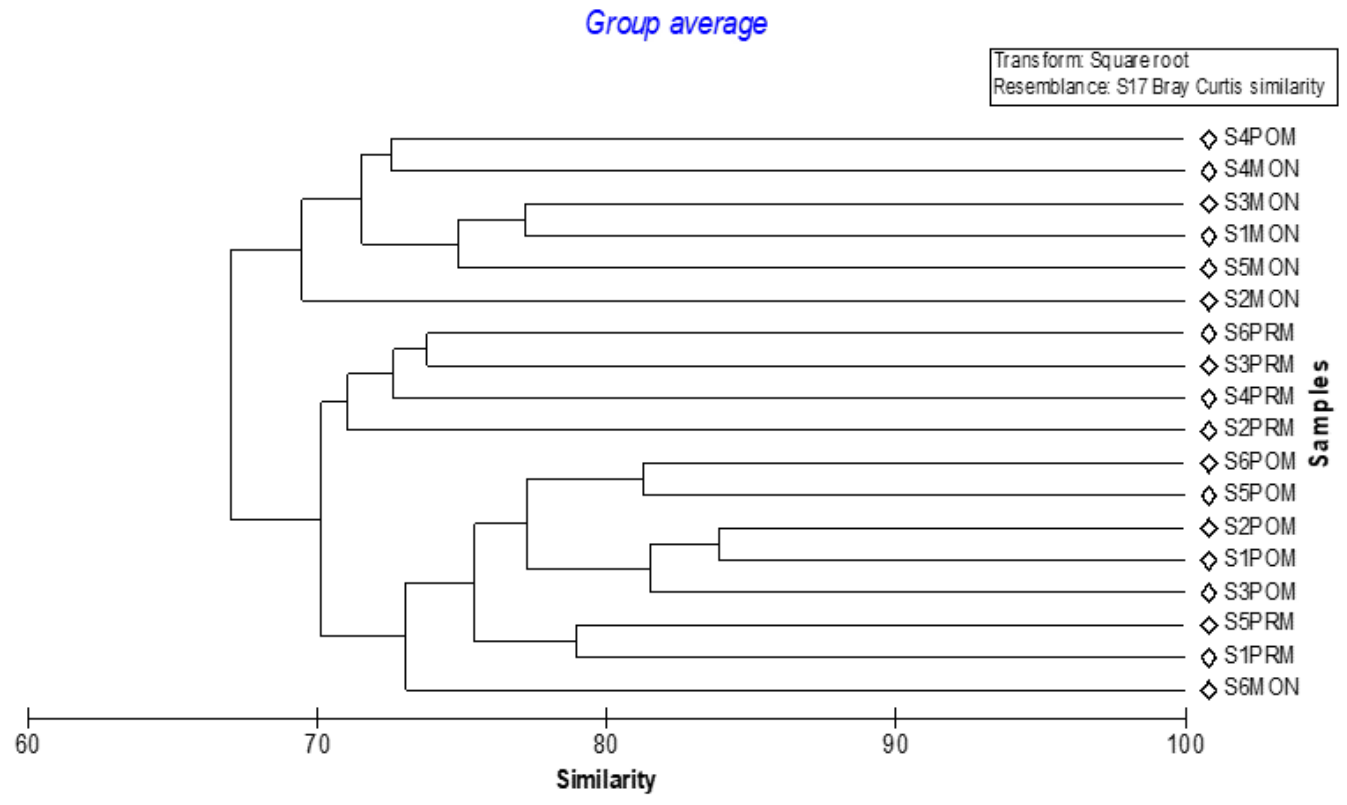

\section{Figure 5}

Dendogram showing the similarity of the stations in different seasons 


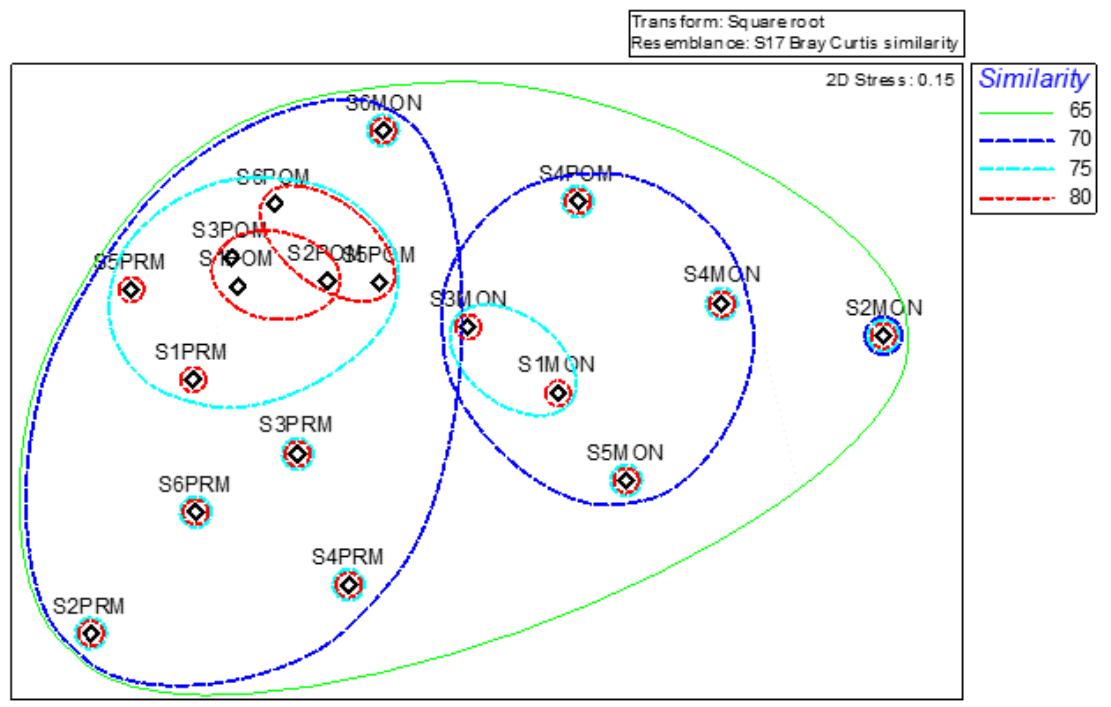

Figure 6

Non metric dimensional scaling map of the zooplankton community in the studied stations
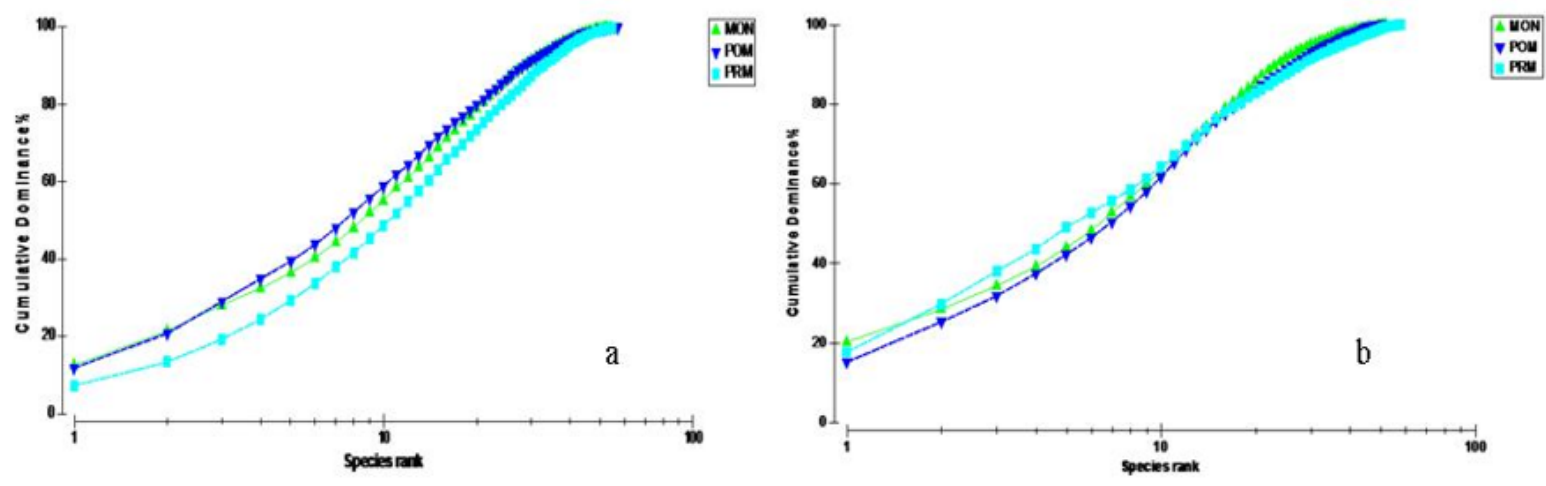

Figure 7

a \& b k-dominance curve plotted in different seasons during the period of 2016-17 and 17-18 


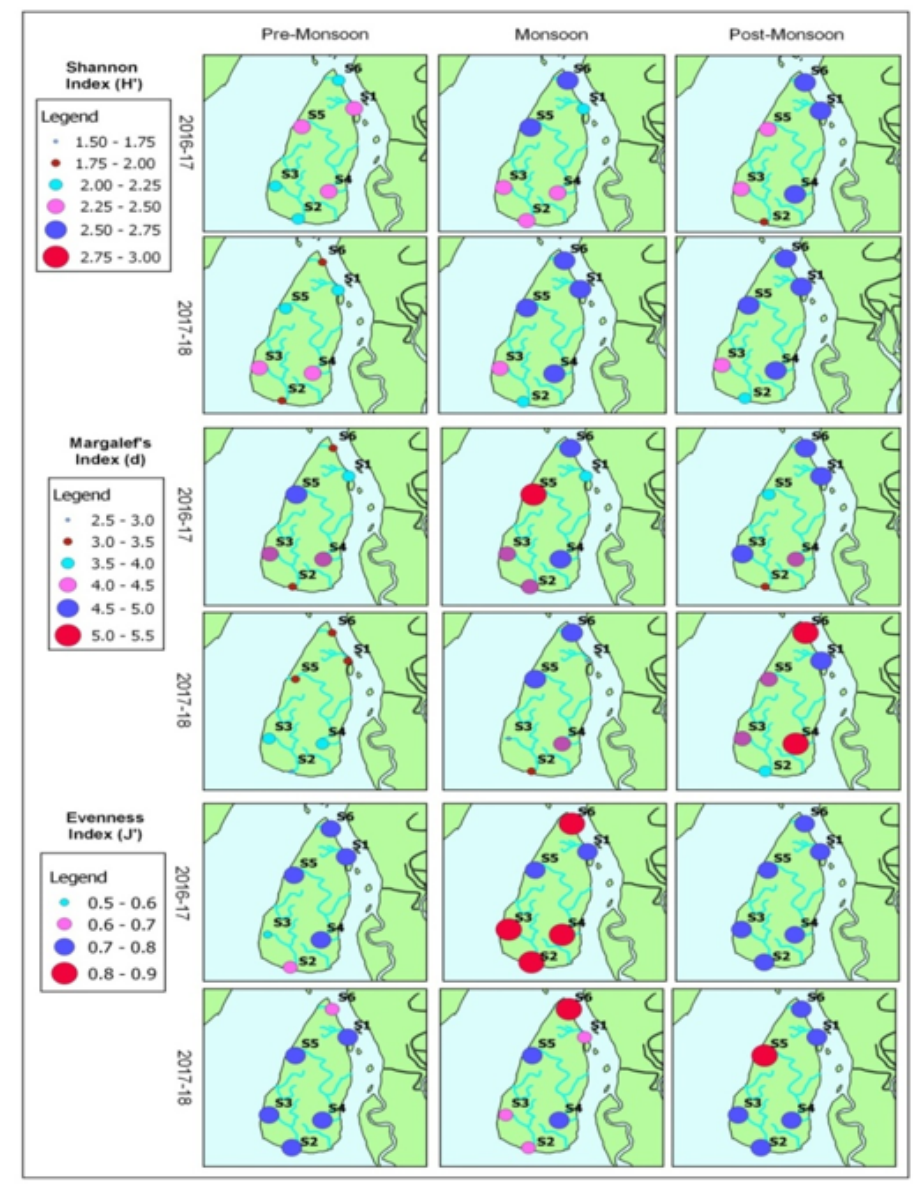

Figure 8

Univariate measures of diversity indices at the sampling stations in different seasons, with superimposed bubbles of the values of diversity indices. Note: The designations employed and the presentation of the material on this map do not imply the expression of any opinion whatsoever on the part of Research Square concerning the legal status of any country, territory, city or area or of its authorities, or concerning the delimitation of its frontiers or boundaries. This map has been provided by the authors. 